NBER WORKING PAPER SERIES

TESTING FOR THE ECONOMIC IMPACT OF THE U.S. CONSTITUTION:

PURCHASING POWER PARITY ACROSS THE COLONIES VERSUS ACROSS THE STATES, 1748-1811

\author{
Farley Grubb \\ Working Paper 13836 \\ http://www.nber.org/papers/w13836 \\ NATIONAL BUREAU OF ECONOMIC RESEARCH \\ 1050 Massachusetts Avenue \\ Cambridge, MA 02138 \\ March 2008
}

The author is Professor and NBER Research Associate in the Economics Department at the University of Delaware, Newark, DE 19716 USA. E-mail: grubbf@lerner.udel.edu. Webpage: http://myprofile.cos.com/grubbf16. Preliminary versions were presented at the 2005 meeting of the Allied Social Science Association in Philadelphia, the 60th International Atlantic Economic Conference in New York, Clark University, Harvard University, Tulane University, University of British Columbia, University of Delaware, University of Mississippi, and University of Paris X-Nanterre. The author thanks the participants of these seminars and Howard Bodenhorn, John Brown, Michel Boutillier, Max Edling, Marc Flandreau, Leslie Goldstein, David Kiriazis, Robert McGuire, Jon Moen, Hugh Rockoff, David Stockman, Remzi Uctum, and Marc Weidenmier for helpful comments on earlier drafts, and thanks Gillian Hamilton and Angela Redish for help with Canadian sources. Financial support provided by a 2003-2004 American Philosophical Society Sabbatical Fellowship Grant, resource support provided by Harvard University Department of Economics, research assistance provided by Alexis Chaves, and editorial assistance provided by Tracy McQueen are gratefully acknowledged. The views expressed herein are those of the author(s) and do not necessarily reflect the views of the National Bureau of Economic Research.

NBER working papers are circulated for discussion and comment purposes. They have not been peerreviewed or been subject to the review by the NBER Board of Directors that accompanies official NBER publications.

(C) 2008 by Farley Grubb. All rights reserved. Short sections of text, not to exceed two paragraphs, may be quoted without explicit permission provided that full credit, including $\odot$ notice, is given to the source. 
Testing for the Economic Impact of the U.S. Constitution: Purchasing Power Parity across the Colonies versus across the States, 1748-1811

Farley Grubb

NBER Working Paper No. 13836

March 2008, Revised August 2009

JEL No. D02,F15,F54,N11,N21,N41,N71,O24,O51

\begin{abstract}
The U.S. Constitution removed real and monetary trade barriers between the states. By contrast, these states when they were British colonies exercised considerable real and monetary autonomy over their borders. Purchasing power parity is used to measure how much economic integration between the states was gained in the decades after the Constitution's adoption compared with what existed among the same locations during the late colonial period. The U.S. Constitution's net contribution to the economic integration of the nation is found, using this method, to be not as large as is commonly supposed.
\end{abstract}

\author{
Farley Grubb \\ University of Delaware \\ Economics Department \\ Newark, DE 19716 \\ and NBER \\ grubbf@lerner.udel.edu \\ http://myprofile.cos.com/grubbf16
}




\section{Testing for the Economic Impact of the U.S. Constitution: Purchasing Power Parity across the Colonies versus Across the States, 1748-1811}

The U.S. Constitution removed real and monetary trade barriers between the states. By contrast, these states when they were British colonies exercised considerable real and monetary autonomy over their borders. Purchasing power parity is used to measure how much economic integration between the states was gained in the decades after the Constitution's adoption compared with what existed among the same locations during the late colonial period. The U.S. Constitution's net contribution to the economic integration of the nation is found, using this method, to be not as large as is commonly supposed.

No idea is more firmly planted in American history than the idea that one of the most difficult problems during the Confederation was that of barriers to trade between state and state. There had been such barriers in colonial times...

$$
\text { Merrill Jensen, New Nation, p. } 337
$$

The 'secret' of American economic growth, English legal scholar Sir Henry Maine wrote in 1886, lay in 'the [constitutional] prohibition against levying duties on commodities passing from State to State.... It secures to the producer the command of a free market over an enormous territory of vast natural wealth...'

Charles W. McCurdy, “American Law,” p. 631

In 1787, three years after the Treaty of Paris ended the Revolution, the founding fathers

crafted a new constitution. This U.S. Constitution, ratified by the states and then adopted by

Congress in 1789 , united the states into one country both politically and economically to a

greater extent than what had existed under the preceding Articles of Confederation or under

British rule prior to 1776 . It required state governments to relinquish their sovereign power to

place revenue duties on commerce with other states and foreign nations, as well as relinquish

their sovereign power to emit fiat paper monies and determine what could be legal tender within

their jurisdictions. The Constitution also required national tariffs on imports from outside the

U.S. to be uniform across the states and prohibited export tariffs (Article 1, Sections 8, 9, and

10). In short, it swept away trade barriers, both real and monetary, between the states and did so

with constitutional force and certainty. It made the United States a common market. 
Today we enjoy the fruits of integrated national markets and look back to the Constitution as the watershed institutional change that created those markets. ${ }^{1}$ But did it really? How much extra economic integration was gained by adopting the Constitution - a lot, a little, or next to nothing? Did it represent a discrete break in the economic integration of the nation? To answer such questions, the economic integration among the states soon after the adoption of the Constitution should be measured against the economic integration that would have occurred under the next best institutional alternative to the Constitution regarding interstate trade rules. ${ }^{2}$

\section{FINDING A BENCHMARK FOR COMPARISON}

If the U.S. had not adopted the Constitution exactly as written, what would have been the alternative? Some Federalist rhetoric of the day and some current scholars presume that it would have been chaos and Armageddon or at best, the Articles of Confederation which by some accounts was the same thing as chaos and Armageddon. But is that the next best viable or likely alternative? It is abundantly clear in the writings of the day that something was going to be changed in the 1780s; either the Articles of Confederation would be amended or some new constitution adopted. One significant impediment to the ratification of the Constitution was the degree by which it restricted state economic sovereignty. ${ }^{3}$ Thus, if the founding fathers had offered a constitution in 1787 in all other respects exactly like the one actually written but with fewer restrictions on state economic sovereignty, it would have likely been ratified as well. Because such was considered at the Constitutional Convention in the summer of 1787 , the prior drafts that offered different interstate trade rules can serve as an approximate identifier of a likely alternative constitution with respect to such rules and their effect on economic integration. ${ }^{4}$

Regarding interstate trade rules, how did these early drafts differ from that eventually adopted? The first complete working draft of a constitution incorporating the Convention's 
deliberations from May $25^{\text {th }}$ (the start of the Convention) through July $26^{\text {th }}$ was presented to the Convention by the Committee of Detail on August $6^{\text {th }}$. It stated, "No State, without the consent of the Legislature of the United States, shall...lay imposts or duties on imports..." No other restrictions on state trade powers were stated. In other words, states could impose revenuegenerating export duties and other non-tariff regulations at will and, as long as Congress did not disallow them, they could also impose revenue-generating import duties. ${ }^{5}$ Only near the end of the Convention on August $28^{\text {th }}$ was the Constitution amended to restrict states from imposing export duties without congressional consent and, more importantly, amended to absolutely stop states from keeping any revenue from state duties on imports and exports. At the Convention, James Madison considered this last restriction as effectively eliminating all state tariffs. ${ }^{6}$ By contrast, the prior drafts of the Constitution basically replicated the colonial system with Congress replacing the British Board of Trade. While Congress, like the British Board of Trade, was given oversight power - the right of consent to state tariff legislation, states under these prior drafts enjoyed considerable latitude over their own revenue-generating tariff polices just as their colonial antecedents had — certainly more than the Constitution as adopted gave to them.

With regard to state monetary powers, in the initial deliberations and drafts in the Committee of Detail (July $17^{\text {th }}$ through August $4^{\text {th }}$ ), they came close to adopting the colonial monetary system — replacing British with congressional oversight. ${ }^{7}$ State legislatures could issue fiat paper money as long as Congress did not disallow such actions_-much like what the British Board of Trade could do during the colonial period. States could determine legal tender within their jurisdictions at least for public debts, but could not determine legal tender in their dealings with the national government or in cross-state trade - again much like what the British Currency Acts in the late colonial period achieved. It was only near the end of the Convention that this 
position was completely overturned and a no-exceptions ban on anything resembling the colonial monetary system was adopted. Supporters argued that this change would increase interstate economic integration. For example, during the ratification debates Madison argued, "Had every State a right to regulate the value of its coin, there might be as many different currencies as States; and thus the intercourse among them would be impeded..."8

In conclusion, with regard to aspects of the Constitution that affected the nation's internal economic integration among the states the next viable and likely alternative was a constitution exactly like the one adopted in 1789 but with the restrictions on state economic sovereignty, both real and monetary, being less absolute and more akin to that experienced by the colonies prior to the Revolution - with Congress replacing the British Board of Trade with regard to oversight powers on these matters. This observation is critical. While the actual economic integration of the nation in the decades soon after the adoption of the Constitution can be measured, what that integration would have been in those decades under the next most likely alternative constitution cannot be directly measured because such is a hypothetical counterfactual world. A real world alternative that can be measured needs to be found that can be taken as a close proxy to that counterfactual world. The degree of market integration observed among the colonies in the decades prior to the Revolution is not only the closest proxy that can be found, but their institutional constraints closely match what the early drafts of the Constitution at the Constitutional Convention would have created with respect to interstate trade rules. Finally, setting counterfactual assessments aside, simply knowing how the economic integration of the U.S. in the decades soon after the adoption of the Constitution compares with that in the decades preceding the Revolution is interesting in its own right, particularly in terms of identifying contributors to long-run economic growth. 
The Exercise of Colonial Economic Sovereignty over Their Borders

The colonies were more-or-less free to pass laws regulating their own trade including placing revenue-generating tariffs on imports and exports that crossed their borders. They were also free to create inside fiat paper monies that could be, only within their jurisdictions, accepted as a legal tender for various subsets of transactions, such as paying local taxes. To varying degrees many enacted and carried out such laws. They faced oversight by the British Board of Trade, but nothing near the absolute restrictions imposed on the states by the U.S. Constitution.

At various times various colonies had import tariffs on finished goods, slaves, servants, convicts, immigrants, pitch, tar, turpentine, rum, wine, beer, other liquors, tea, horses, cattle, sheep, swine, beef, pork, butter, cheese, rice, hops, flax, sugar, molasses, vessels, empty casks, tobacco, salt, cacao, dry goods, bar iron, wood products, animal skins, biscuits, foodstuffs, soap, and non-British European and East Indian goods. Similarly, at various times various colonies had export tariffs on tobacco, meat, fish, board lumber, animal skins, tanned leather, bread and flour, timber, and barrel staves. Differential tonnage duties were imposed by various colonies at various times as well. Colonies did not impose the same tariff duties on the same products, and colonies altered their duties from year to year on some products. Some colonies were able to pass laws imposing duties on goods imported from neighboring colonies. For some colonies import and export duties represented a substantial portion of that colonial government's revenue whereas in other colonies they represented next to nothing or were not even used. In addition, some colonies had excise taxes on products such as tobacco, tea, wine, liquors, lemons, oranges, and limes. Excise taxes on products not produced in that colony would be functionally equivalent to placing an import tariff on said goods. Finally, some colonies at various times also imposed 
non-tariff trade regulations, such as inspection rules, restrictions on when and where markets could operate, and institutionalized price controls of varying degrees. ${ }^{9}$

The exercise of sovereign power by individual colonies over the trade that crossed their borders had some constraints. First, colonial laws had to be approved by the British Crown - in the late colonial period via the Board of Trade - with the exception of Connecticut and Rhode Island whose laws were not subject to Crown review. The Board typically let colonial trade laws stand except for a few of the most egregiously disruptive, vis-à-vis their effect on neighboring colonies or on important traders within the Empire. For example, when the colony of New York tried to impose a 10 percent tariff upon goods imported from neighboring colonies the Crown disallowed it. Oliver Dickerson concluded that "The policy of the Board on the subject of intercolonial commerce is...clear..., although there are fewer instances of its use. The few instances of action, however, were effective in preventing the growth of discriminating trade laws" within the Empire. Yet, a number of direct revenue-generating interfering duties between colonies can be documented to have been not disallowed by the Board or not disallowed in a timely fashion. ${ }^{10}$

Second, import and export duties affecting neighboring colonies faced retaliatory actions that often led to their removal or alteration. For example, New Hampshire's export duty on lumber prompted Massachusetts to retaliate by imposing duties on the importation of New Hampshire merchandise which in turn led New Hampshire to repeal its export duty on lumber. Pennsylvania imposed reciprocal duties on goods imported from New York and Maryland that would remain in force until its neighboring colonies removed their comparable duties. To what extent these two constraints mitigated trade-barrier creation between colonies and stopped markets from being poorly integrated is an empirical matter that will be estimated below. ${ }^{11}$ 
The colonies also exercised considerable sovereign power over their own monetary policies. They were allowed to issue their own fiat paper currencies, which at various times some did and some did not. The amounts issued, the timing of emissions, and their backing or redemption structures, along with their exchange rates to sterling, were allowed to and did vary considerably from colony to colony. There was little coordination of monetary policy across the colonies and no ability by colonies to enforce a fixed exchange rate between fiat currencies and specie by directly exchanging it for specie on demand. Colonial treasuries could not and did not function like banks in the $19^{\text {th }}$ century sense. The British Parliament's Currency Acts of 1751, 1764,1770 , and 1773 constrained the colonies' monetary behavior but only in limiting the maximum duration between emission and redemption in some colonies and, in all colonies, limiting the extent to which paper money could be made a legal tender for debts. Considerable flexibility in the exercise of monetary policy remained across the colonies - certainly far more than the absolute ban on such activities written into the U.S. Constitution. ${ }^{12}$

The exercise of sovereign power by individual colonies over the real and monetary trade barriers at their borders, and the frequent and uncertain changes in these barriers, could create large and varying cost wedges between colonial markets thus thwarting market integration among the colonies. Because the Constitution removed these sovereign powers from the states, the expectation is that markets should be less integrated among the colonies than among the same post-Constitution states. The early drafts of the Constitution at the Constitutional Convention with respects to interstate trade rules replicated this colonial world with Congress playing the role of the British Board of Trade. As such, the difference between the market integration among the post-Constitution states and that among the same locations when they 
were colonies — used here as a proxy for the relevant counterfactual—measures the net contribution to the economic integration of the nation attributable to the U.S. Constitution. ${ }^{13}$

\section{PURCHASING POWER PARITY AND MARKET INTEGRATION}

What can be used as a comparable method of estimating economic integration that also is feasible given the current data? One such measure is purchasing power parity (PPP hereafter)which measures how well the prices of goods in two markets approximate the law-of-one-price after accounting for exchange rates between the markets. Full purchasing power parity in absolute terms would imply that at any point in time

$$
\mathrm{EX} a b=\mathrm{P} a / \mathrm{P} b,
$$

where EXab is the exchange rate between places $a$ and $b, \mathrm{P} a$ is the price index of goods in place $a$ in terms of currency in place $a$ and $\mathrm{P} b$ is the price index of goods in place $b$ in terms of currency in place $b$. In the absence of barriers to trade, both tariff and non-tariff, profit arbitrage among merchants should drive the PPP equation toward holding with equality. Because transportation costs act as a wedge between markets and because shocks are not always fully anticipated, the PPP equation is not expected to hold instantly and absolutely, but only relatively and with some equilibrating time needed. ${ }^{14}$ As such, the PPP equation is typically estimated in terms of rates of change over time.

$$
\ln \mathrm{y}_{\mathrm{t}}=\ln \mathrm{EX} a b_{\mathrm{t}}+\ln \mathrm{P} b_{\mathrm{t}}-\ln \mathrm{P} a_{\mathrm{t}}
$$

where $\mathrm{t}$ is time in years, and $\mathrm{y}$ is the yearly deviations from PPP.

Given integrated markets, deviations from PPP should be arbitraged away. Thus, a standard test of PPP, and hence of market integration, is to determine if the deviations from PPP (the $\operatorname{lny}_{\mathrm{t}}$ 's) are stationary over time, i.e. whether the presence of unit roots can be rejected. Nonstationary deviations (unit roots) indicate the presence of tax, transaction, information, 
transportation, and/or institutional costs between these markets that are thwarting the profitability of arbitrage and the free flow of goods. More importantly, even if deviations from PPP are stationary, the time it takes them to mean-revert when shocks push them off their stationary path - the half-life - can be used as a relative measure of the magnitude of the arbitrage costs and trade barriers that are preventing these markets from being instantly integrated. As such, whether or not deviations from long-run PPP are permanent and how long it takes shocks to mean-revert can be considered one measure of how well two market locations are integrated. ${ }^{15}$ PPP can also be cast in the counterfactual terms needed to assess the magnitude of institutional change. Across the states, does PPP hold to a greater degree, or to what degree do shocks to PPP mean-revert faster, in the years shortly after the adoption of the Constitution compared with across these same locations when they were British colonies? While PPP isn't the only test of the economic impact of the U.S. Constitution, it is an instructive place to start. PPP gets directly at the economic integration question, and it requires little evidence, i.e. only price indices and exchange rates. Other approaches are more data constrained, less direct, and not as easily cast in clear counterfactual terms. ${ }^{16}$

\section{DATA, TIME SPANS, AND EMPIRICAL DESIGN}

\section{Empirical Design}

A four-way empirical comparison is used to isolate the source of change in market integration - a difference-in-difference setup. ${ }^{17}$ First, PPP among six post-Constitution statesMassachusetts, New York, Pennsylvania, Maryland, Virginia, and South Carolina—is estimated and compared with PPP among their colonial antecedents. This comparison is the main counterfactual assessment to the questions posed above, namely what is the net contribution of the U.S. Constitution to increasing market integration within the nation. 
Second, PPP between Canadian locations-Montreal and Quebec_-post-U.S. independence is estimated and compared with PPP between these locations pre-1776. This is done to determine whether changes in market integration over time are unique to the U.S. experience. The U.S. went through major institutional changes that supposedly affected market integration. Canadian locations did not. If Canadian locations experienced improvements to market integration over time similar to that experienced by U.S. locations, it would be difficult to attribute the improvements in U.S. market integration solely to the adoption of the U.S. Constitution.

Third, PPP is estimated between Canadian locations and non-Canadian (future U.S.) locations prior to 1776 . This is done to determine whether PPP among the colonies was more-orless uniform - a member of the British Empire effect—or was unique to just future U.S. states. In other words, how successful as a general system was oversight by the British Board of Trade and potential retaliatory behavior among the colonies at maintaining market integration? This comparison helps determine whether an alternative U.S. Constitution where states exercised sovereignty over the trade that crossed their borders conditional on congressional oversight similar to that exercised by the British Board of Trade over the colonies could have been a viable system for achieving market integration within the United States.

Fourth, PPP is estimated between U.S. states and Canadian locations during the post-U.S. Constitution period. This result, in conjunction with the second and third comparison, determines whether the first comparison is unique to the U.S. or merely part of some global change overtime. It also provides a relative comparison for determining whether the sovereign-bordereffect on market integration was more potent at the colony/state level or at the national level. 
PPP comparisons require data on prices and exchange rates per location as well as the selection of a time span for estimating PPP. Surviving data constrain what can be done.

\section{Prices}

Separate continuous price indices per year, one for each colony/state market location, are needed to measure market integration via PPP. The long-established price indices for Massachusetts, Pennsylvania, New York, and South Carolina and the price indices recently created for Montreal and Quebec are used here. Added to these, are price indices constructed by the author for Maryland and Virginia from raw individual price series. These price indices from 1748 through 1811 are presented in Figure 1 and $2 .{ }^{18}$ They are heavily weighted toward tradable goods, thus the possibility of PPP failure due to the presence of non-tradable goods is largely removed. ${ }^{19}$ While the available price data constrain the PPP tests to measuring market integration between only eight locations across British North America, the six locations (states) that would become united politically and monetarily under the U.S. Constitution after 1789 comprised two-thirds of the U.S. population and an even higher share of U.S. output and exports in this era. These six locations also represent an equal number of northern and southern states.

\section{[Places Figures 1 and 2 Here]}

\section{Exchange Rates}

For the colonial period, each price index reported above was expressed in a different currency, either that colony's unit-of-account currency or its paper currency if it had issued such in this period. Thus, to estimate PPP between the eight locations above for which price indices exist, separate and continuous exchange rates per year between the currencies of each location are needed. Such direct exchange rates between these locations do not exist. However, they can be indirectly calculated using the long-established exchange rates between each location's 
currency and pounds sterling, presented here in Figure $3 .^{20}$ The indirect exchange rate between two locations $[\mathrm{EX} a b]$ can be estimated by taking the ratio of each location's exchange rate to pounds sterling $[\mathrm{EX} a b=\mathrm{EX} a £ / \mathrm{Ex} b £]^{21}$

\section{[Place Figure 3 Here]}

The exchange rates between any two U.S. states in the post-Constitution period is assumed to be one [EXab=1]. Being a specie coin, a U.S. dollar is a U.S. dollar regardless of location. And while the medium of exchange in the U.S. was comprised of a plethora of U.S. dollar-denominated private banknotes, foreign specie coinage, and U.S. dollar specie coins, all price indices in the U.S. data used here after 1795 were recorded in U.S. specie dollars. As such, the test of PPP across U.S. states is also a test of whether the assumption of a unitary exchange rate in U.S. dollars across states is a reasonable approximation once market participants had converted whatever other monies were in use into the U.S. specie dollar unit of account.

In the post-Constitution period direct exchange rates between Canada and U.S. states do not exist. The Canadian locations used a unit-of-account currency called the Halifax pound. An indirect exchange rate between U.S. dollars and Halifax pounds can be estimated in the same manner as was done above for the colonial period. The Halifax pound to pounds sterling exchange rate divided by the U.S. dollar to pounds sterling exchange rate equals the Halifax pound to U.S. dollar exchange rate. ${ }^{22}$

\section{Time Span Selection}

PPP is a time series analysis and so requires a span of continuous data. Because the goal is to compare market integration among a group of locations post-Constitution with that among the same group in the colonial era, panel time series techniques that group the locations together in each period are the most appropriate. Such techniques can be sensitive to nuisance events 
which could bias the outcome, such as crossing different regimes or random occurrences of historically unique events. ${ }^{23}$ For example, the trauma produced after 1811 by the War of 1812 and the lapse of the charter of the First Bank of the U.S. should not be confused with the Constitution's failure to yield integrated markets. As such, selecting periods, both postConstitution and pre-Revolution, that are relatively regime-homogenous is preferred.

For the post-Constitution period the time span selected for estimation is from 1796 through 1811. The Constitution was not adopted by Congress until 1789 and its effects on market integration were likely not instantaneous. For example, it took a few years to get related monetary institutions up and running. The First Bank of the U.S. was not established until 1791, with its various branches taking several years to open, and the U.S. mint was not established until 1792. In addition, vestiges of pre-Constitution state institutions took a few years to be displaced in the marketplace. For example, as late as 1795 some of the newspaper price currents used to construct the price indices used here quoted their prices in pounds, shillings, and pencethe old state currencies - rather than in U.S. dollars. Thus, 1796 is the earliest date when it seems clear that post-Constitution behavior is not tainted by hold-over vestiges of pre-Constitution pricing and institutions. Figures 1 and 2 also show a large non-stationary price spike occurring in the early 1790s. Thus, if an earlier date is picked it would likely diminish the magnitude of market integration estimated for the post-Constitution period. As such, 1796 is taken as the starting point for testing PPP in the post-Constitution era. ${ }^{24}$

The year 1811 is taken as the end testing point because the War of 1812 produced a substantial liquidity crisis and one of the largest price inflations between the Revolution and the Civil War. The charter for the First Bank of the U.S. was also allowed to lapse in 1811, and so 1811 marks a monetary institutional transition point and thus an appropriate data end point. ${ }^{25}$ In 
addition, the Constitution's effect on interstate market integration cannot be disentangled from that of the transportation revolution post-1815 using PPP methodologies. A time span that runs significantly past 1815 would lack relevance. In short, the period 1796 to 1811 was selected because it represents, as best as can be selected, a relatively homogenous institutional regime across U.S. states for the post-Constitution period. It provides the best pure case and biggest effect possible for increased market integration among the states attributable to the Constitution.

For the colonial period, the time span ends in 1775 and is extended back as far as either the data allow for each location or until a major regime change is encountered. Lower Canada (Montreal and Quebec) did not fall under British administration until after 1760 - and price indices and exchange rates are not available before then. ${ }^{26}$ The price indices used for Massachusetts and Maryland go back to 1750 and 1756, respectively, and Virginia did not start to issue paper money until after 1755 with Virginia prices and exchange rates not reflecting said until about 1757, which explains the beginning dates for these five locations. The New York price index does not go back before 1748, thus explaining the start date for that location. While the Pennsylvania and South Carolina data go back even further, being only two locations, starting before 1748 for Pennsylvania and South Carolina would not be that informative.

For the colonial period the end of King George's War (1748) is also a good starting point because 1748 is arguably a turning point in colonial monetary behavior. The wartime inflation prior to 1748 caused Massachusetts to go off paper money after 1749 and led the British Parliament to pass the Currency Act of 1751 which allowed colonies to issue paper money if two conditions were met: (1) that it not be legal tender for all debts, and (2) that ample provisions (taxes) be put in place to redeem each issue "within as short and reasonable a time as may be, not exceeding five years as the farthest". While this Act only applied to New England - the legal 
tender prohibition was extended to non-New England colonies by the Currency Act of 1764Maryland, Pennsylvania, and New York had followed similar policies on their own accord well before 1760. For the spans of data used in the colonial period Massachusetts, Montreal, and Quebec used a non-paper-money unit-of-account currency, the Massachusetts pound and Halifax pound, respectively. The other five colonies were on their own individual paper currency standards. Prices in each colony were typically quoted in their respective fiat paper monies when they had one or in their unit-of-account currency when they did not issue paper money. ${ }^{27}$ In short, the period 1775 back to 1748 (or as close to 1748 as possible) was selected because it represents, as best as can be selected, a relatively homogeneous institutional regime within each colony and so between the colonies prior to the American Revolution.

\section{Preliminary Data Evaluation}

Before proceeding to test PPP between colonies and between states, i.e. before testing the combined movement of price indices and exchange rates between locations, it is important to note the properties of each price index and exchange rate for each separate location on its own. ${ }^{28}$ For the price indices displayed in Figures 1 and 2 for the colonial period, the New York series is non-stationary while the rest are trend stationary, but with different trends among the locations. In addition, the half-lives to shocks vary among these series. For the exchange rates displayed in Figure 3, the Massachusetts and Virginia series are non-stationary while the rest are stationary, but with half-lives to shocks that vary among these series. For the price indices in the postConstitution period, 1796-1811, Montreal is non-stationary, Quebec and South Carolina are trend stationary, but with very different trends, and the rest are stationary with only minor differences in their half-lives to shocks. The exchange rate to pounds sterling in this period for Montreal and Quebec is non-stationary, whereas the U.S. dollar to pounds sterling exchange rate is stationary. 
In summary, the vast majority of individual time-series used here are either stationary or trend stationary. Thus, combining series via co-integration techniques is unnecessary (cointegration being used to see if individual non-stationary series when combined become stationary). Conversely, PPP holding across locations simply cannot be deduced from the fact that the individual series that make up the PPP equation are stationary. The fact that the trends and half-lives to shocks vary substantially among the various individual series, plus the fact that a few of the series are non-stationary or only marginally stationary, leaves PPP holding, let alone the magnitude by which it might hold, an open question. Simply eyeballing the separate series in Figures 1, 2, and 3 does not produce a confident feel for how integrated these locations may be in terms of PPP. ${ }^{29}$ As such, econometric estimation of the properties of the lny,'s from the PPP equation is still required. If nothing else estimation is necessary to produce a measure of the halflives to shocks. The magnitude of these half-lives is the key to comparing colonial versus postConstitution market integration.

\section{PPP TEST PROCEDURES AND RESULTS}

Table 1 presents several panel tests as well as the full complement of univariate augmented Dickey-Fuller tests for unit roots (non-stationarity) in the PPP equation residuals among the eight locations described above for the late colonial period (1748-1775) and the early U.S. national period (1796-1811). To compare market integration among a group of locations post-Constitution with market integration among the same group in the colonial era, panel timeseries techniques that group the locations together in each period are the most appropriate. Panel techniques are also recommended as a way to mitigate the low-powered problem inherent in univariate tests when using short spans of data, i.e. the difficulty univariate tests have distinguishing between non-stationarity and stationarity with slow convergence. ${ }^{30}$ 
[Place Table 1 Here]

Because panel tests vary in terms of how individuals in the panel are combined, how they perform in finite samples, and how the alternative to the null hypothesis of non-stationarity is constructed, it is important for robustness purposes to report a variety of panel tests. As such, all the panel tests currently available in STATA are reported here. The workhorse is the Levin-LinChu test in part because it is recommended for smaller panels and because it generates a coefficient $\left(\mathrm{a}_{1}\right)$ from which a half-life to shocks can be calculated. It tests the null that all individuals in the panel have a unit root against the alternative that all are stationary. It has moderate ability to reject the null when the truth is a mixed panel in which some individuals have unit-root processes while others do not. The second panel test reported, the Im-PesaranShin test, relaxes the homogeneity restriction in the alternative hypothesis of the Levin-Lin-Chu test, replacing it with the union of stationarity outcomes among the individuals in the panel.

Both the Levin-Lin-Chu and the Im-Pesaran-Shin test must be used on balanced panels. This is not an issue for the post-Constitution period where all individuals have the same time span. For the colonial period the panels must be estimated anew for a different span of years each time another colony enters the data set. Results from these two panel tests are also reported for different groupings in each period, such as for including Lower Canada versus not including Lower Canada. This, along with the univariate tests, helps identify where the relative strengths of market integration lay within each panel grouping. Finally, two variants of the Fisher panel test for unbalanced panels are reported, one using augmented Dickey-Fuller methods and one using Phillip-Perron methods. These last two tests can be thought of as pooled univariate tests. ${ }^{31}$

Panel unit-root tests have some drawbacks. First, they do not reveal where within the panel the strengths and weakness in market integration lay, i.e. whether all individuals are 
equally integrated or whether some individuals suffer from unit-root processes while others do not. Because of this, it is important to report the full complement of univariate tests between individual location pairings in the panel as a diagnostic tool and robustness check. These univariate tests are presented in Table 1 after the panel tests. Second, cross-sectional independence in the regression error terms is a regular assumption of panel tests. While the time spans are too short to definitively test for this, the fact that the price indices used for the eight locations do not have a single good in common and often have a number of non-overlapping goods in their index compositions, mitigates against the possibility that global shocks to common goods might be imparting some non-independence across regression residuals. ${ }^{32}$

\section{Results for the Colonial Period}

A unit-root process is rejected (PPP holds) in all panel tests for the colonial period regardless of test, time span, or location grouping. The half-lives to shocks in the panel tests are relatively short, being about half a year, except when Virginia is included and Lower Canada is excluded. Then it rises to about one year, which is still reasonably short. Given this data and using these methods, colonial markets appear well integrated. Despite a fair degree of practical sovereignty over their borders with respect to real and monetary trade barriers, the colonies did not exercise this sovereignty in a way to seriously inhibit the profitability of arbitrage and the free flow of goods. Weak British oversight and the threat of retaliatory action between colonies may have been enough to maintain market integration. ${ }^{33}$

The univariate tests support the panel results and show that the results are spread evenly across the panel. A unit root can be rejected (PPP holds) for 27 of the 28 pairings. ${ }^{34}$ In addition, the half-lives to shocks are uniform across pairings, ranging between one-third and two-thirds of a year for most — only exceeding one year in three of the 28 pairings. Only Virginia exhibits 
some structural break issues. For all colonies paired with Virginia in a univariate setting a unit root cannot be rejected (results not shown). However, once a structural break is added so that 1757-1765 is different from 1766-1775, then a unit root is rejected. This makes sense for Virginia because unlike the other colonies Virginia had no experience issuing paper money before 1755 and engaged in poor money management early on. Complaints about Virginia were, in part, responsible for the passage of the 1764 Currency Act which supposedly corrected Virginia's behavior. ${ }^{35}$ Nevertheless, the panel results, which do not incorporate the structural break in Virginia's behavior, show that this weakness in Virginia's PPP is minor.

\section{Results for the Post-Constitution U.S. States}

The panel tests are mixed regarding PPP holding among the post-Constitution U.S. states. The Im-Pesaran-Shin test fails to reject a unit root (PPP does not hold) except when South Carolina is excluded from the sample space and then only barely rejecting a unit root. By contrast, the Levin-Lin-Chu test rejects a unit-root process (PPP holds) for all groupings. However, the half-lives to shocks in these tests are relatively long at 1.5 years for the six U.S. states. This is between one-third and one-half longer than what is estimated among the panel tests in the colonial period. Only when South Carolina is dropped from the post-Constitution panel does the half-life to shocks improve into the range estimated for the colonial period.

The univariate tests support the panel results and show that the primary problem lies with South Carolina. PPP among U.S. states holds for 10 of the 15 pairings. PPP fails to hold for the Maryland-Pennsylvania pairing (just missing the 10 percent significance level) and for 4 of the 5 South Carolina pairings. The half-lives to shocks, excluding the South Carolina pairings, is comparable to that in the colonial period, confirming that it is something about South Carolina that is making market integration among the U.S. states look worse than among the colonies. 
Given the totality of estimates in Table 1, the general impression is that when applying the same methods and test criteria PPP holds marginally better across the six colonies that would be future U.S. states than it does across the same locations post-Constitution. At best, the colonial and early national periods are indistinguishable in terms of PPP. Relatively short halflives to shocks are found, which explains why a unit root can be rejected in most cases in both periods even when using short data spans and univariate tests. These relatively short half-lives are consistent with colonial and early national markets being reasonably well integrated with the exception of post-Constitution South Carolina.

Quantitatively, the net contribution of the Constitution to increasing market integration among the states can be measured as minus the difference in the half-life to shocks postConstitution versus pre-Revolution. ${ }^{36}$ Comparing the panel estimate for the six states in the postConstitution period $\left(\mathrm{S}_{1}\right)$ with the worst result in the panel estimates for these same six locations in the colonial period $\left(\mathrm{S}_{3}\right)$ yields a net gain in market integration of $\left[\right.$ minus $\left.\left(\mathrm{S}_{1}-\mathrm{S}_{3}\right)\right]=-0.38$. Thus, even when selecting results biased in favor of the Constitution causing increased market integration among the states, a marked deterioration is found instead. Only if South Carolina is dropped from the post-Constitution panel can a case be made for improved market integration post-Constitution, i.e. the best case in Table 1 being $\left[\right.$ minus $\left.\left(\mathrm{S}_{1} *-\mathrm{S}_{3}\right)\right]=+0.62$.

Market integration as measured by PPP across U.S. states was not improved by the U.S. Constitution compared with what it was in the late colonial period. The key economic clauses in the Constitution that removed real and monetary trade barriers between the states had little effect compared with its likely and almost-adopted alternative, namely a constitution just like the one adopted in 1789 but with restrictions on state economic sovereignty over the trade that crossed their borders, both real and monetary, being less absolute and more akin to that experienced by 
the colonies prior to the Revolution but with the U.S. Congress replacing the British Board of Trade with regard to oversight powers on these matters.

\section{Robustness Checks: The South Carolina Anomaly Post-Constitution}

The failure of PPP to hold for most South Carolina pairings with other U.S. states in the early national period compared with PPP holding for all South Carolina pairings in the colonial period might be due to changes in the composition of goods in the South Carolina price index. Between 1748 and 1775 the South Carolina price index is heavily weighted toward rice and indigo, 51 and 22 percent, respectively. Cotton received zero weight. Between 1796 and 1811 the South Carolina price index is heavily weighted toward cotton, i.e. 32 percent of the index. The patenting of Eli Whitney's cotton gin in 1794 and the explosion in cotton production after 1795 drove cotton prices down. ${ }^{37}$ When the South Carolina price index is separated into its subcomponents, it shows that indeed cotton prices declined precipitously between 1796 and 1811, more so than for other goods, see Appendix Figure A. Given cotton's weight in the index, South Carolina's price index was dragged down relative to the price indices of other states.

Removing cotton from the South Carolina price index might improve PPP for South Carolina pairings in the early national period. Table 2 reports univariate augmented DickeyFuller tests for PPP between South Carolina and the other U.S. states and with Lower Canada for when the South Carolina price index is restricted to its reported subcomponents. The results show that export staple prices, in particular cotton prices, are a substantial contributor to the PPP failure of South Carolina pairings. However, removing export staples or just using rice prices from the South Carolina index, while moving the estimate toward PPP holding, does not improve the estimates enough in any pairing to statistically reject PPP failure at the 10 percent level. 
When restricting the Pennsylvania index to be as close to South Carolina's cotton-only index and to South Carolina's rice-only index in terms of measuring the same products, the Pennsylvania Textile Fiber Price Only Index and the Pennsylvania Grain Price Only Index, respectively, PPP failure still cannot be statistically rejected. The failure of PPP to hold for most South Carolina pairings in the post-Constitution period would appear to be relatively robust. Difference-In-Difference Controls and Sovereign Border Effects: The Results for Lower Canada

The deterioration of market integration among U.S. states post-Constitution compared with pre-Revolution [minus $\left(\mathrm{S}_{1}-\mathrm{S}_{3}\right)$ in Table 1] might simply reflect some general deterioration of market integration among North Atlantic economies over this period. In other words, the Constitution might still be seen as improving market integration among the states if market integration in nearby locations that did not experience U.S. style institutional changes suffered even more deterioration. The difference in market integration in terms of the half-life to shocks between Montreal and Quebec after $1795\left(\mathrm{C}_{1}\right)$ compared with before $1776\left(\mathrm{C}_{3}\right)$ will be used to net out such a possibility using a difference-in-difference assessment, i.e. minus $\left[\left(\mathrm{S}_{1}-\mathrm{S}_{3}\right)-\left(\mathrm{C}_{1}\right.\right.$ $\left.-\mathrm{C}_{3}\right)$ ] in Table $1 .^{38}$ Even when biasing the outcome in favor of the Constitution having an improving effect on economic integration among the states by the selection of $\left(\mathrm{S}_{1}-\mathrm{S}_{3}\right)$ and by assuming $\mathrm{C}_{3}=0$, the results, while less negative than when Lower Canada is not used as a control, are still negative (-0.04). Again, only if South Carolina is dropped from the panel of U.S. states (replacing $S_{1}$ with $S_{1} *$ ) can a positive effect be generated.

The Canadian results can also be used to assess changes in market integration when national sovereign borders change. American independence and the economic integrating effects of adopting the U.S. Constitution manifested itself among U.S. states as a group, i.e. not as an improvement in PPP or market integration among U.S. states but as an inside versus outside the 
British Empire effect. Table 1 tests PPP between Lower Canada and the U.S. states both before U.S. independence (1761-1775) and after the adoption of the Constitution (1796-1811). The PPP estimates reveal an erosion of market integration between Lower Canada and U.S. locations after the U.S. left the British Empire.

In both the panel and univariate tests involving Lower Canada during the colonial period PPP failure can be rejected with confidence. The half-life to shocks between Lower Canada and non-Lower Canada are similar to those among the non-Lower Canada colonies. Lower Canada cannot be distinguished from non-Lower Canada before the American Revolution.

Post-U.S. Constitution, the univariate tests show that PPP continues to hold between Montreal and Quebec but now fails to hold between Montreal and all other U.S. states and between Quebec and all other U.S. states. The panel tests show a similar result in that they are weak and mixed on PPP holding when Lower Canada is included in the sample space. The halflife to shocks - two to three years - is much longer when Lower Canada is included in the panel compared with the 0.5 to 1.5 years when excluded.

Market integration between Lower Canada and the U.S. parted ways post-Constitution. The Constitution allowed U.S. states as a group to chart a course separate from that of Lower Canada, e.g. the Jefferson embargo. Lower Canada was tied to the British economy. It remained part of the British Empire which maintained substantial trade barriers against nations outside the Empire which now included the United States. Britain also went to war with France, suffered inflation, and went off the gold standard in 1797. The U.S. states were able to decouple their economies from Britain, not go to war, not go off a specie monetary standard, and not suffer as much inflation relative to the British and Canadian economies. ${ }^{39}$ As such, these results are 
consistent with the relative importance of international sovereign borders as an impediment to PPP found in studies of the modern era. ${ }^{40}$

\section{WHY DID THE CONSTITUTION FAIL TO IMPROVE PPP AMONG U.S. STATES?}

Part of the answer may be that market integration was so good among the colonies, despite their exercise of real and monetary sovereignty over their borders, that there was little room for improvement. ${ }^{41}$ Still, as good as colonial market integration was, why did adopting the Constitution not yield even more improvement? Several possible reasons exist. First, the Constitution did not restrict states from enacting excise taxes, taxes familiar to most colonists. An excise tax placed on a product not produced within the state is equivalent to an import duty placed on that product. ${ }^{42}$ However, when the Constitution eliminated the ability of the states to raise revenue through imposing import and export duties at their borders, states did not shift to excise taxes to replace the lost revenue. Before the adoption of the Constitution, states relied on poll and property taxes and land sales as their primary revenue sources. After the adoption of the Constitution, states continued to rely almost exclusively on these sources. They simply dropped the revenue earned on import and export duties without replacing it with other taxes. Federal assumption of state war debts in 1790 significantly reduced state expenses and so made this possible. ${ }^{43}$ State excise taxes that inhibited interstate market integration would not reappear until later in the $19^{\text {th }}$ century. They were unimportant pre- $1812 .^{44}$

New York was an exception. From 1784 through 1811 it maintained a tax on the auction of "merchandise and effects of foreign production imported into the state" and after 1801 an additional charge of one percent per value sold when auctioned in New York City. Auction duties may have served as a surrogate for a tariff on foreign imports depending on what portion of these imports were sold at auction versus through other means. New York's revenue from 
auction duties was not trivial. For example, in 1799 the state collected \$47,908 in auction duties which represented 19 percent of total revenue for that year. While not directly affecting the movement of U.S. produced goods into New York from other states, except wine and spirits for which auction duties applied regardless of origin, these auction duties could have produced some price wedges between foreign goods in New York and the same foreign goods in other states and so inhibited better interstate market integration. ${ }^{45}$

Second, the constitutional clause restricting state power to erect tariffs had an exception, namely states could place duties on imports or exports without congressional consent if they were "absolutely necessary for executing its [the states'] inspection laws..."-Article 1, section 10, clause $2 .^{46}$ States could erect trade barriers against other states in the guise of inspection laws, though they could not retain any revenue from such duties beyond the fees needed to defray the cost of inspection. While these fees were typically small relative to the price of the good, the total time, effort, money, and resources expended on inspection was nontrivial. States made extensive use of inspection laws placing them on many important trade goods.

Only a few state inspection laws targeted imports, such as gunpowder imported into Pennsylvania. Most targeted goods produced within their respective states that were to be exported. For example, Pennsylvania required inspection of flour, bread, beef, pork, flaxseed, butter, biscuits, shingles, staves, Indian corn, hog-lard, and black-oak bark produced in Pennsylvania that were to be exported from the state; Maryland required said for tobacco, potash, bacon, beef, pork, fish, flour, and bread; Virginia required said for tobacco, flour, bread, fish, pork, beef, tar, pitch, turpentine, and ship ballast; and South Carolina required said for tobacco, beef, pork, rice, pitch, tar, rosin, turpentine, shingles, staves, cotton, bread, flour, corn, peas, potatoes, oats, wheat, and rye. These inspection laws applied to goods exported to other states as 
well as to foreign countries, but not to goods consumed within state. This fact is illustrated by Virginia who altered its law in 1802 to exempt flour shipped to the District of Columbia from inspection. This change turned the District of Columbia from an outside to an inside market vis-à-vis Virginia with respect to flour prices. In general, inspection laws were not uniformly enforced and they were changed from time to time. ${ }^{47}$ They created varying price differentials between goods sold within-state versus when the same goods were sold out-of-state thereby inhibiting better interstate market integration. It took most of the $19^{\text {th }}$ and some of the $20^{\text {th }}$ century to eliminate such behaviors via Federal and Supreme Court action. ${ }^{48}$

Third, because "deviations from PPP are always and everywhere a monetary phenomenon," constitutional changes in monetary institutions need to be reevaluated. ${ }^{49}$ The U.S. Constitution eliminated competing state-issued monies and led to a common national currencyof-account (the U.S. Dollar) under a fixed specie exchange rate regime. This shift should have increased national market integration. ${ }^{50}$ That it did not as measured by PPP here suggests that some countervailing forces may have been at work. For example, the Constitution did not create a common paper medium of exchange and, in fact, occasioned a greater number of paper currencies (different banknotes) than what had existed during the late colonial era. PostConstitution, there was a rapid increase in the number of privately run banks chartered by state governments, from only 3 in 1787 to 76 by 1805 . These banks issued banknotes backed by fractional reserves of specie. A wide range of banknotes entered cross-state trade. The notes facilitated trade but at the cost of banknotes trading at varying discounts off their face value, depending on distance to the issuing bank and that bank's reputation. This may have increased the transactions costs of cross-state arbitrage to a level comparable with what existed in the late colonial era of floating exchange rates between the fiat paper currencies issued by each colonial 
legislature (a maximum of 13 separate currencies). Monetary union did not mean financial union. Financial market integration by some measures would take another century or more to achieve. Even a common national paper currency exchangeable at par throughout the country would take another 75 years to achieve. ${ }^{51}$ As such, better interstate market integration post-Constitution may have been inhibited because a common unit-of-account currency and so unitary exchange rates between states, as assumed in the price indices reported post-1795 and used here in Table 1 to estimate PPP, was not yet completely achieved.

This last inhibiting factor to better interstate market integration may have been particularly acute for South Carolina. As shown above, market integration among the states was comparable with that among their colonial antecedents as long as South Carolina is excluded from the post-Constitution sample. The poor PPP performance of post-Constitution South Carolina stands out as anomalous. Besides creating interstate trade barriers via inspection laws and local banknote currencies, actions undertaken in most states, South Carolina went further than other states in subverting the constitutional restriction on states issuing bills of credit and making them a legal tender for paying state obligations. ${ }^{52}$

In 1786 South Carolina issued 100,000 South Carolina pounds as loan-office bills of credit - paper money the state government loaned to its citizens who mortgaged their lands as security. These bills were receivable at par with specie for repaying said loans and for state taxes. Initially these bills were to be called out of circulation by 1791 , but every year thereafter through 1811 the state legislature extended the period of their acceptance, at par with specie, for repayment of the loans made in these bills that were still due. The South Carolina legislature also explicitly made, by law, paper vouchers paid to legislators in this period a legal tender for paying state taxes. Both these actions gave a nominal anchor to these old state paper bills of credit and 
current legislator pay vouchers and so may have maintained these instruments as credible inside-

monies within South Carolina. ${ }^{53}$ The maintenance of non-specie-linked inside monies competing with specie-linked outside monies in South Carolina between 1790 and 1811 may have inhibited better interstate market integration.

\section{PAST AND PRESENT}

In the modern era it has been difficult not to reject PPP using standard univariate tests, both in inter-national comparisons — especially for floating exchange rate regimes—and in intranational comparisons, such as across U.S. cities where tariff barriers and exchange rate volatility do not exist. While panel data approaches have made it easier not to reject PPP, the meanreversion process has often remained long. Shocks appear to be stubbornly persistent in ways that are difficult to explain in terms of the cost of arbitrage, i.e. half-lives of typically 3 to 5 years, and in some cases, such as between major U.S. cities from 1918 to 1995, a half-life of almost 9 years. $^{54}$

How does the past compare with this? In other words, was it always like this or when did such complications in PPP arise? If we take the late colonial and early national periods in America as the past, then the past appears very different indeed. In the colonial and early national periods, even when using low-powered univariate tests and short spans of data, for the most part PPP holds and the shocks to PPP have low persistence, i.e. half-lives of 1 or less years, see Table 1 . Yet in these early periods transactions, information, and transportation costs were higher compared with the modern era — working against the finding here. That implies that the difference in present versus past PPP measures must be attributable to other differences. For example, in these earlier periods the complexity of goods was on average lower and marketinstitutional price-stickiness was lower, monetary institutions were simpler, and technical change 
or differential non-transferable real productivity shocks were lower than during the modern era. Thus, if PPP holds less easily in the modern era, then it may be the rise in these latter factors that complicated trade cost and measurement accuracy and made it difficult to find that PPP holds and/or causes shock-persistence to be relatively high. ${ }^{55}$

For the modern era, scholars have also found that the degree to which PPP holds is affected by sovereign borders and by exchange rate regimes. Typically, PPP is more difficult not to reject and the persistence of deviations to PPP are higher under floating exchange rates and where national borders intrude. ${ }^{56}$ The results in Table 1 go in the opposite direction of these modern era findings in terms of exchange rate regimes and in terms of colonial versus state sovereign borders (though in the same direction regarding international sovereign borders - the U.S. versus Lower Canada). This comparison again points to the increasing complexity of modern monetary institutions, informal non-tariff trade barriers, and modern goods, and the rise of differential non-transferable real productivity shocks, as the culprits behind the relative failure of PPP and higher persistence of deviations from PPP in the modern era rather than just sovereign borders and exchange rate regimes per se.

Finally, a few long-run tests of PPP using pre-modern European data, such as for wheat prices between England and France from 1630 to 1789, have also rejected unit roots using standard univariate tests and found low persistence to deviations to PPP, i.e. half-lives of about one year. ${ }^{57}$ As such, the modern era versus pre-modern era comparisons offered here, being before versus after the industrial revolution, might also be seen as broadly consistent with the interpretation of PPP failure (or the high persistence of shocks) in the modern era as being possibly due to the rise in the complexity of modern goods, modern monetary institutions, and non-easily transferable real productivity shocks. 


\section{CONCLUSIONS}

Institutional change may matter, but sometimes not by much, and sometimes not in ways obvious to us or foreseen by their creators. The U.S. Constitution gives the appearance of sweeping away both real and monetary trade barriers between the states thus enhancing national market integration. But in fact it may not have done so, at least not over the lifetimes of its creators, relative to a next best alternative - a looser confederation similar to that within the British Empire where individual colonies (states) exercised considerable real and monetary sovereignty over their borders, but with the U.S. Congress substituted into the oversight role played by the British Board of Trade vis-à-vis the states. As such, adopting the Constitution was not a watershed institutional change or a discrete break with the past with regard to national market integration. Long-run economic growth predicated on increasing market integration within the nation brought on by institutional change cannot be sustained using the methods and evidence here. Market integration during 1796-1811 was not superior to that during 1748-1775.

While the net contribution of the Constitution to U.S. interstate market integration in the first decades of the Republic may be nil, the Constitution might still be credited with constraining future market disintegration that might have arisen in its absence, and it allowed future generations via judicial re-interpretation and Federal action to sweep away state trade barriers centuries later. In addition, while constitutionally changing the economic sovereignty of state borders may have mattered little, changing the economic sovereignty of national borders mattered a lot. After 1795 a gap in market integration opened up between the U.S. and what remained of the British Empire in America, a gap that did not exist before 1776.

I realize that there are an army of scholars with strong priors regarding the Constitution's triumph in creating a common market within the United States soon after its adoption, along with 
the benefits that flowed from that creation. I was one of them. Such priors, however, come from a priori logic and not systematic measurement done within a counterfactual framework. While the results here attempt to bridge this gap between logic and empirics, they are based on PPP methodologies using the currently available data — methods and data that are not perfect. While there may be other approaches to testing the economic impact of the Constitution, using relative PPP performance is the obvious and direct approach. Given that it indicates that the Constitution added little to U.S. national market integration in the early decades of the Republic, we can no longer just assume that it is a priori obvious that the Constitution produced substantial gains in national economic integration soon after its adoption.

[Place Appendix Tables A and Appendix Figure A Here] 


\section{REFERENCES}

Adams, Donald R. Jr. "Prices and Wages in Maryland, 1750-1850.” This Journal 46, no. 3 (1986): 625-45.

Adams, Henry Carter. "Taxation in the United States, 1789-1816.” Johns Hopkins University Studies in Historical and Political Science 2, no. V-VI (1884): 267-341.

Bailyn, Bernard, ed. The Debate on the Constitution. New York: Literary Classics, Vols. 1-2, 1993.

Becker, Robert A. Revolution, Reform, and the Politics of American Taxation, 1763-1783. Baton Rouge, LA: Louisiana State University Press, 1980.

Bezanson, Anne, Robert D. Gray, and Miriam Hussey. Wholesale Prices in Philadelphia, 1784-1861. Philadelphia: University of Pennsylvania Press, 1936.

Bordo, Michael D., and Ivan A. Marcotte. "Purchasing Power Parity in Colonial America: Some Evidence for South Carolina 1732-1774, a Comment." Carnegie-Rochester Conference Series on Public Policy 27 (1987): 311-24.

Bordo, Michael D., and Eugene N. White. "British and French Finance During the Napoleonic Wars.” In Monetary Regimes in Transition, edited by Michael D. Bordo and Forrest Capie, 241-73. New York: Cambridge University Press, 1994.

Brock, Leslie V. The Currency of the American Colonies, 1700-1764. New York: Arno, 1975. Brodhead, John Romeyn. History of the State of New York. Second Volume. New York: Harper \& Brothers, 1871.

Brooks, Robert Preston. The Financial History of Georgia, 1732-1950. Athens, GA: University of Georgia, 1952.

Bruchey, Stuart. The Roots of American Economic Growth, 1607-1861. New York: Harper \& 
Row, 1965.

Bullock, Charles T. "Historical Sketch of the Finances and Financial Policy of Massachusetts." Publications of the American Economic Association 8, no. 2 (1907): 269-412.

Cecchetti, Stephen G., Nelson C. Mark, and Robert J. Sonora. "Price Index Convergence Among United States Cities.” International Economic Review 43, no. 4 (2002): 1081-99.

Cole, Arthur Harrison. Wholesale Commodity Prices in the United States, 1700-1861. Cambridge, MA: Harvard University Press, 1938.

Cooper, Thomas, ed. The Statutes at Large of South Carolina, Volume 5. Columbia, SC: A. S. Johnson, 1839.

Dickerson, Oliver Morton. American Colonial Government, 1696-1765. Cleveland, OH: Arthur H. Clark Company, 1912.

Dickinson, Rodolphus. A Digest of the Common Law, the Statutes Laws of Massachusetts. Deerfield, MA: John Wilson, 1818.

Dougherty, Keith L. Collective Action under the Articles of Confederation. New York: Cambridge University Press, 2001.

Edling, Max M., and Mark D. Kaplanoff. “Alexander Hamilton’s Fiscal Reform: Transforming the Structure of Taxation in the Early Republic.” William and Mary Quarterly 61, no. 4 (2004): 713-44.

Elmer, Lucius Quintius Cincinnatus. A Digest of the Laws of New Jersey. Bridgton, NJ: Elmer \& Nixon, 1861.

Engel, Charles, and John H. Rogers. "How Wide Is the Border?” American Economic Review 86, no. 5 (1996): 1112-25.

Enders, Walter. Applied Econometric Time Series. New York: John Wily \& Sons, 1995. 
Ernst, Joseph Albert. Money and Politics in America, 1755-1775. Chapel Hill, NC: University of North Carolina Press, 1973.

Farrand, Max, ed. The Records of the Federal Convention of 1787. New Haven, CT: Yale University Press, Vols. 1-4, 1966.

Froot, Kenneth A., and Kenneth Rogoff. "Perspectives on PPP and Long-Run Real Exchange Rates.” In Handbook of International Economics, Volume 3, edited by Gene M.Grossman and Kenneth Rogoff, 1647-88. Amsterdam: North-Holland, 1995.

Gopinath, Gita, Pierre-Oliver Gourinchas, Chang-Tai Hsieh, and Nicholas Li. "Estimating the Border Effect: Some New Evidence.” NBER working paper \#14938 (2009): http://www.nber.org/papers/w14938.

Gorodnichenko, Yuriy, and Linda L. Tesar. “Border Effect or Country Effect? Seattle May Not Be so Far from Vancouver After All.” American Economic Journal: Macroeconomics 1, no. 1 (2009): 219-41.

Grubb, Farley. “Creating the U.S. Dollar Currency Union, 1748-1811: A Quest for Monetary Stability or a Usurpation of State Sovereignty for Person Gain?" American Economic Review 93, no. 5 (2003): 1778-98.

. "The Circulating Medium of Exchange in Colonial Pennsylvania, 1729-1775: New Estimates of Monetary Composition, Performance, and Economic Growth.” Explorations in Economic History 41, no. 4 (2004): 329-60.

. "State 'Currencies' and the Transition to the U.S. Dollar: Reply-Including a New View from Canada." American Economic Review 94, no. 4 (2005): 1341-48. . "The US Constitution and Monetary Powers: An Analysis of the 1787 Constitutional Convention and the Constitutional Transformation of US Monetary System." Financial 
History Review 13, no. 1 (2006): 43-71.

. "The Constitutional Creation of a Common Currency in the U.S., 1748-1811: Monetary Stabilization Versus Merchant Rent Seeking." In Conflict Potentials in Monetary Unions, edited by Lars Jonung and Jurgen Nautz, 19-50. Stuttgart: Steiner Verlag, 2007.

Hanna, Hugh Sisson. “A Financial History of Maryland (1789-1848).” Johns Hopkins University Studies in Historical and Political Science 25, nos. 8-10 (1907): 355-481.

Heckelman, Jac C., and Keith L. Dougherty. “An Economic Interpretation of the Constitutional Convention of 1787 Revisited.” This Journal 67, no. 4 (2007): 829-48.

Hening, William Waller. The Statutes at Large; Being A Collection of All the Laws of Virginia, Volume 13. Philadelphia: Thomas Desilver, 1823.

Herty, Thomas. A Digest of the Laws of Maryland. Baltimore: Warner \& Hanna, 1799.

Hill, William. "The First Stages of the Tariff Policy of the United States.” Publications of the American Economic Association 8, no. 6 (1893): 457-614.

Holton, Woody. Unruly Americans and the Origins of the Constitution. New York: Hill and Wang, 2007.

Hood, John. Index of Colonial and State Laws of New Jersey between the Years 1663 and 1903. Camden, NJ: Sinnickson Chew \& Sons, 1905.

Hughes, J. R. T. Social Control in the Colonial Economy. Charlottesville, VA: University Press of Virginia, 1976.

Jensen, Merrill. The New Nation: A History of the United States during the Confederation, 1781-1789. Boston: Northeastern University Press, 1981 [original 1950].

Journals of the Continental Congress, 1774-1789. Vols. 1-34. Washington D.C.: Government Printing Office, 1904-1937. 
Kaplan, Edward S. The Bank of the United States and the American Economy. Westport, CT: Greenwood Press, 1999.

Labaree, Leonard Woods. Royal Government in America. New Haven, CT: Yale University Press, 1930.

Lakwete, Angela. Inventing the Cotton Gin: Machine and Myth in Antebellum America. Baltimore: Johns Hopkins Press, 2003.

Landon-Lane, John, and Hugh Rockoff. "From Monetary Union to Financial Union in the United States." In Conflict Potentials in Monetary Unions, edited by Lars Jonung and Jurgen Nautz, 51-72. Stuttgart: Steiner Verlag, 2007.

Levin, Andrew, Chien-Fu Lin, and Chia-Shang James Chu. "Unit Root Tests in Panel Data: Asymptotic and Finite-Sample Properties.” Journal of Econometrics 108, no. 1 (2002): $1-24$.

Mark, Nelson C. International Macroeconomics and Finance: Theory and Econometric Methods. Oxford, UK: Blackwell, 2001.

Maryland [State of]. A Digest of the Laws of Maryland. Washington, DC: J. C. O'Reilly, 1804. McCullough, A. B. Money and Exchange in Canada to 1900. Toronto: Dundurn, 1984. McCurdy, Charles W. "American Law and the Marketing Structure of the Large Corporation, 1875-1890.” This Journal 38, no. 3 (1978): 631-49.

McCusker, John J. Money and Exchange in Europe and America, 1600-1775. Chapel Hill, NC: University of North Carolina Press, 1978.

McGuire, Robert A. To Form a More Perfect Union: A New Economic Interpretation of the United States Constitution. New York: Oxford University Press, 2003.

McIvor, R. Craig. Canadian Monetary, Banking and Fiscal Development. Toronto: Macmillan, 
1961.

Newman, Eric P. The Early Paper Money of America, $4^{\text {th }}$ Edition. Iola, WI: Krause Publications, 1997.

North, Douglass C. The Economic Growth of the United States, 1790-1860. New York: W. W. Norton, 1966.

Officer, Lawrence H. Between the Dollar-Sterling Gold Points. New York: Cambridge University Press, 1996.

Owing, Donnell MacClure. His Lordship's Patronage: Offices of Profit in Colonial Maryland. Baltimore: Maryland Historical Society and J. H. Furst Company, 1953.

Paquet, Gilles, and Jean-Pierre Wallot. "Some Price Indexes for Quebec and Montreal (17601913)." Histoire Sociale / Social History 62 (1998): 281-320.

Parsley, David C., and Shang-Jin Wei. "Convergence to the Law of One Price Without Trade Barriers or Currency Fluctuations.” Quarterly Journal of Economics 111, no. 4 (1996): 1211-36.

Pennsylvania [State of]. The Statutes at Large of Pennsylvania from 1682 to 1809, Volumes 1118. Harrisburg, PA: State Printers, 1906-1915.

Perkins, Edwin J. The Economy of Colonial America. New York: Columbia University Press, $2^{\text {nd }}$ edn., 1988. . American Public Finance and Financial Services, 1700-1815. Columbus, OH: Ohio State University Press, 1994.

Purdon, John. A Digest of the Laws of Pennsylvania. Philadelphia: Philip H. Nicklin, 1818. Rabushka, Alvin. Taxation in Colonial America. Princeton, NJ: Princeton University Press, 2008. 
Rogoff, Kenneth. "The Purchasing Power Parity Puzzle.” Journal of Economic Literature 34, no. 2 (1996): 647-68.

Rothenberg, Winifred B. “A Price Index for Rural Massachusetts, 1750-1855.” This Journal 39, no. 4 (1979): 975-1001.

Rutland, Robert A., ed. Papers of George Mason. Chapel Hill, NC: University of North Carolina Press, Vol. 2, 1970.

Selgin, George. "The Suppression of State Banknotes: A Reconsideration." Economic Inquiry 38, no. 4 (2000): 600-15.

Shambaugh, Jay C. "An Experiment with Multiple Currencies: The American Monetary System from 1838-60." Explorations in Economic History 43, no. 4 (2006): 609-45.

Shepherd, James F., and Gary M. Walton. Shipping, Maritime Trade, and the Economic Development of Colonial North America. London: Cambridge University Press, 1972.

Shepherd, Samuel. The Statutes at Large of Virginia, From October Session 1792, To December Session 1806, Volumes 1-3. New York: AMS Press, 1970 [original 1835].

Sjölander, Pär. "Unreal Exchange Rates: A Simulation-based Approach to Adjust Misleading PPP Estimates.” Journal of Economic Studies 34, no. 3 (2007): 256-88.

Sowers, Don C. The Financial History of New York State from 1789 to 1912. New York: Columbia University, 1914.

Taylor, Alan M. "Potential Pitfalls for the Purchasing-Power-Parity Puzzle? Sampling and Specification Biases in Mean-Reversion Tests of the Law of One Price." Econometrica 69, no. 2 (2001): 473-98.

Taylor, Alan M. "A Century of Purchasing-Power Parity." Review of Economic Statistics 84, no. 1 (2002): 139-50. 
Taylor, Alan M., and Mark P. Taylor. “The Purchasing Power Parity Debate.” Journal of Economic Perspectives 18, no. 4 (2004): 135-58.

Tindall, George Brown. America: A Narrative History. New York: W. W. Norton, $2^{\text {nd }}$ edn., 1988.

Walradt, Henry F. “The Financial History of Connecticut from 1789 to 1861.” Transactions of the Connecticut Academy of Arts and Sciences 17 (1912): 3-139

Walsh, Lorena. Personal communication. 1999.

Walton, Gary M. “New Evidence on Colonial Commerce.” This Journal 28, no. 3 (1968): 363-89.

Walton, Gary M., and James F. Shepherd. The Economic Rise of Early America. New York: Cambridge University Press, 1979.

Wolcott, Oliver Jr. "Direct Taxes.” American State Papers: Finances 1: 414-7. Washington, DC: Government Publishing Office, 1832 [original 1796]. 


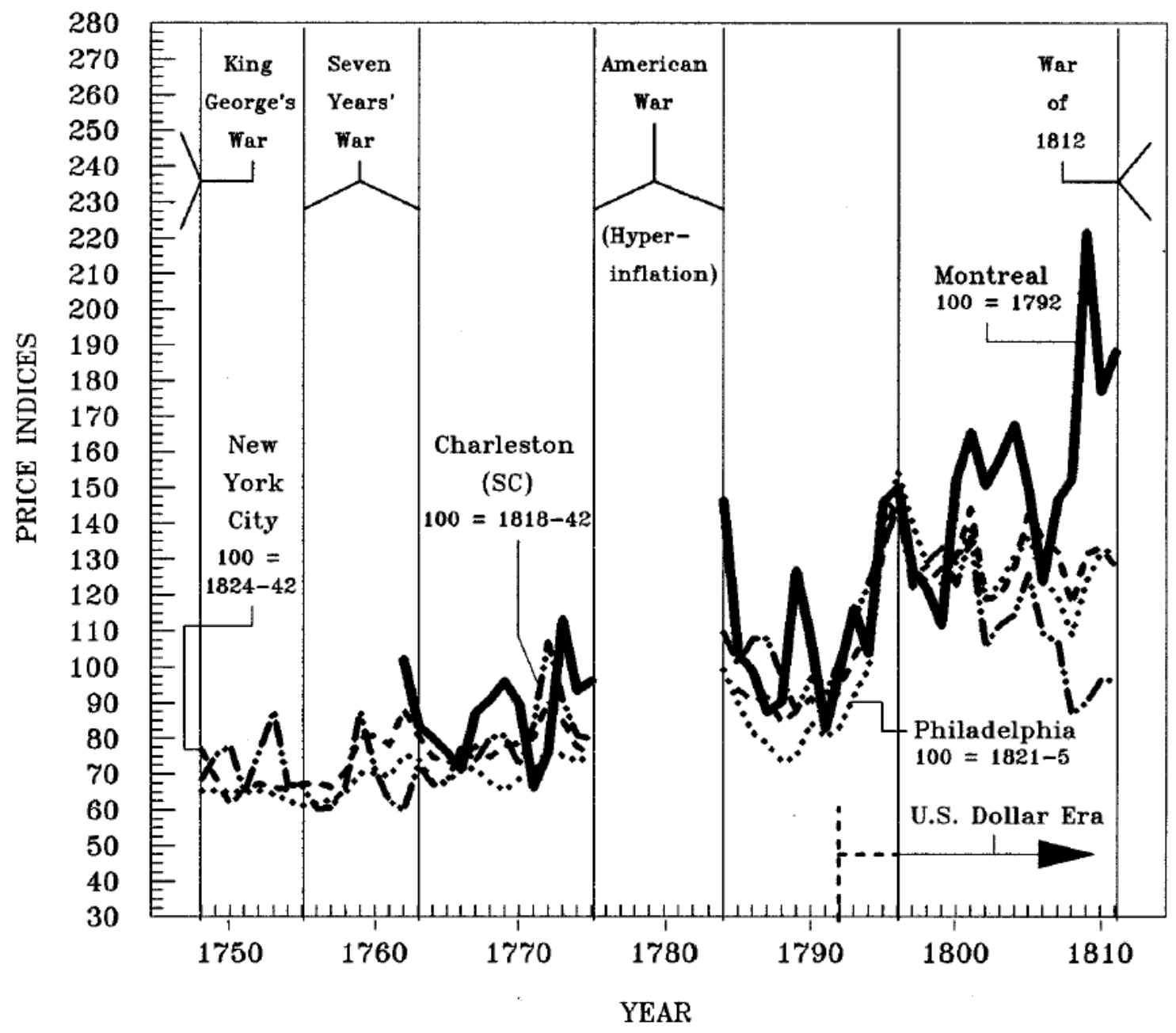

FIGURE 1

PRICE INDICES FOR NEW YORK CITY, NY; CHARLESTON, SC; PHILADELPHIA, PA; AND MONTREAL, CANADA, 1748-1811

Notes and Sources: See the notes to Table 1 below and the text. 


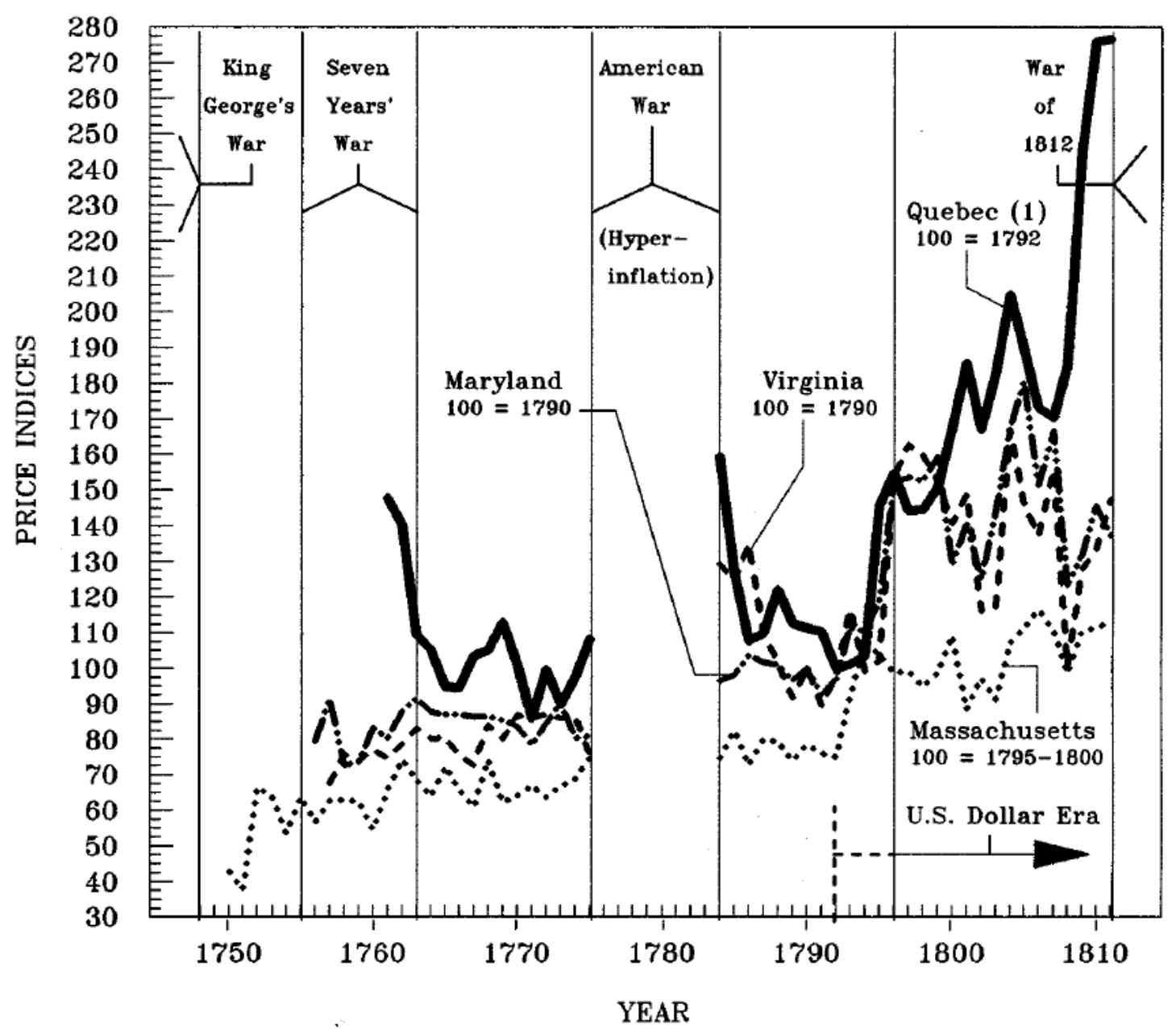

FIGURE 2

PRICE INDICES FOR MARYLAND, VIRGINIA, MASSACHUSETTS, AND QUEBEC, CANADA, 1748-1811

Notes and Sources: See the notes to Table 1 below and the text. 


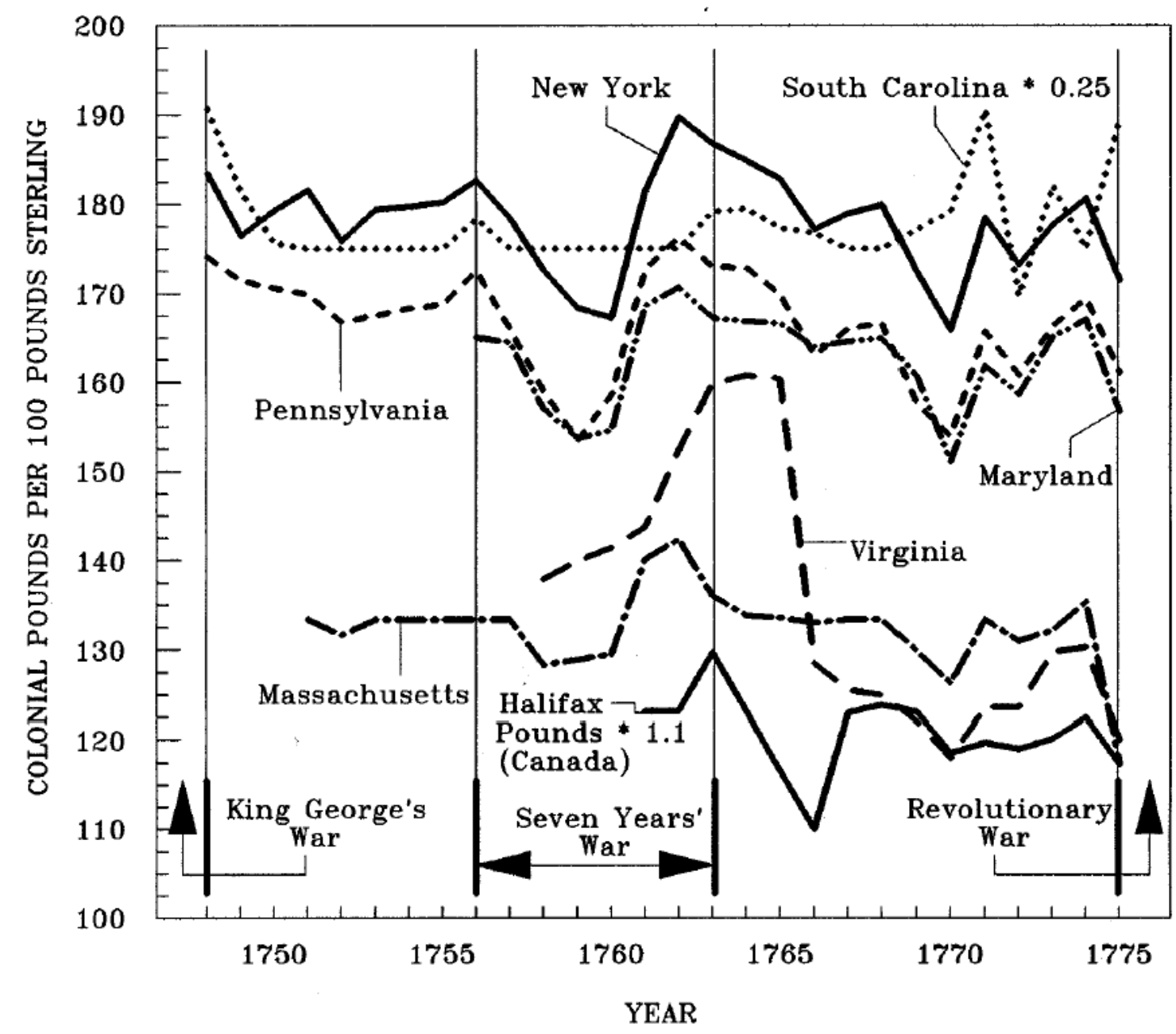

FIGURE 3

EXCHANGE RATES BETWEEN COLONIAL CURRENCIES AND BRITISH POUNDS STERLING, 1748-1775

Notes and Sources: See the notes to Table 1 below and the text. The South Carolina Pound and the Halifax Pound were rescaled to fit within the display range of the other currencies. 
TABLE 1

PANEL AND UNIVARIATE UNIT-ROOT TESTS FOR PPP, 1748-1775 VERSUS 1796-1811

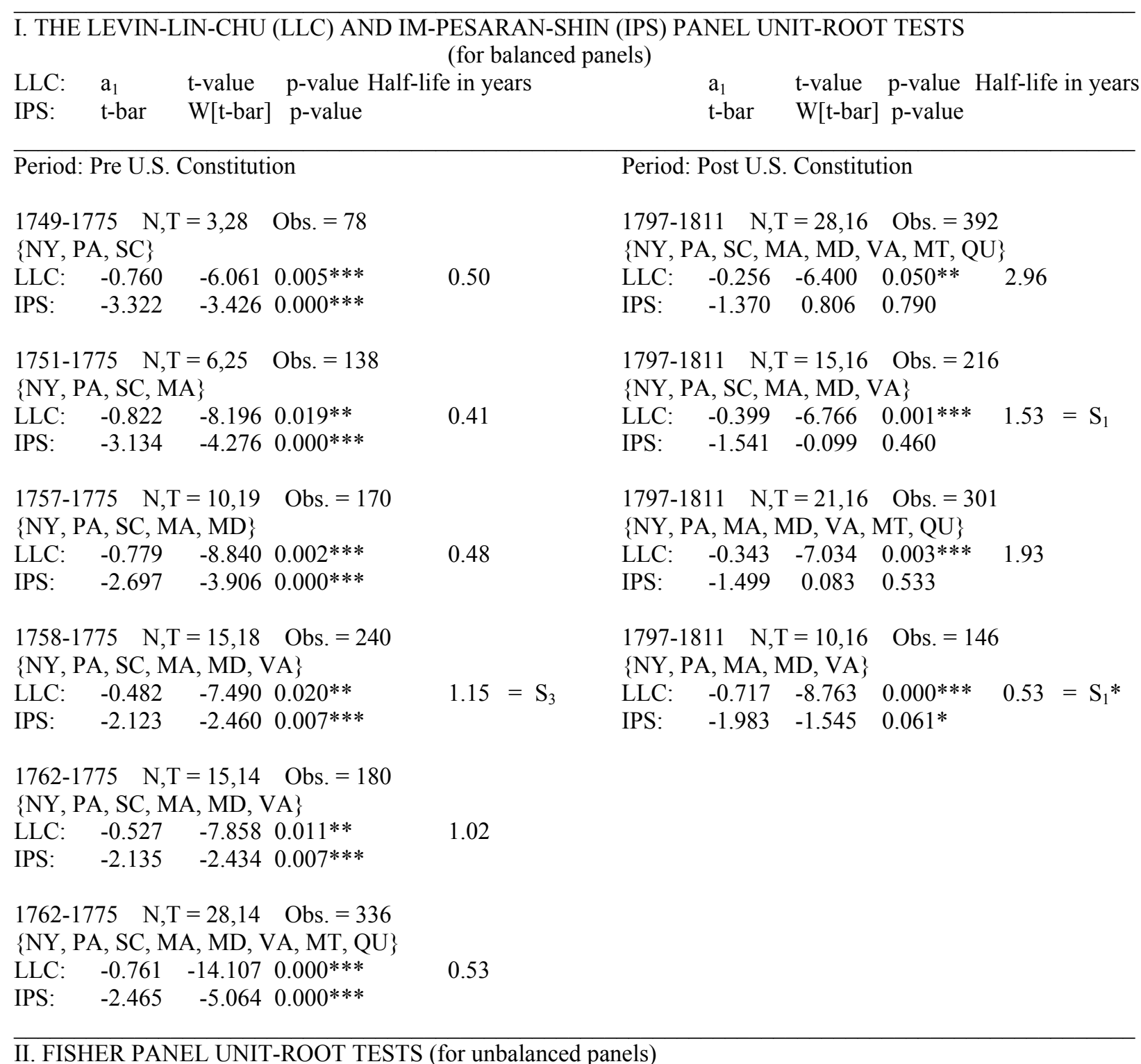

II. FISHER PANEL UNIT-ROOT TESTS (for unbalanced panels)

Period: Pre U.S. Constitution (1749-1775)

Period: Post U.S. Constitution (1797-1811)

[NY, PA, SC, MA, MD, VA, MT, QU]

[NY, PA, SC, MA, MD, VA, MT, QU]

A. Using the Augmented Dickey-Fuller Test

Chi-squared $(56)=91.5093 * * *$

Chi-squared (56) $=46.5096$

B. Using the Phillips-Perron Test

Chi-squared $(56)=367.9349^{* * *}$

Chi-squared $(56)=87.4247 * * *$ 


\section{UNIVARIATE AUGMENTED DICKEY-FULLER UNIT-ROOT TESTS}

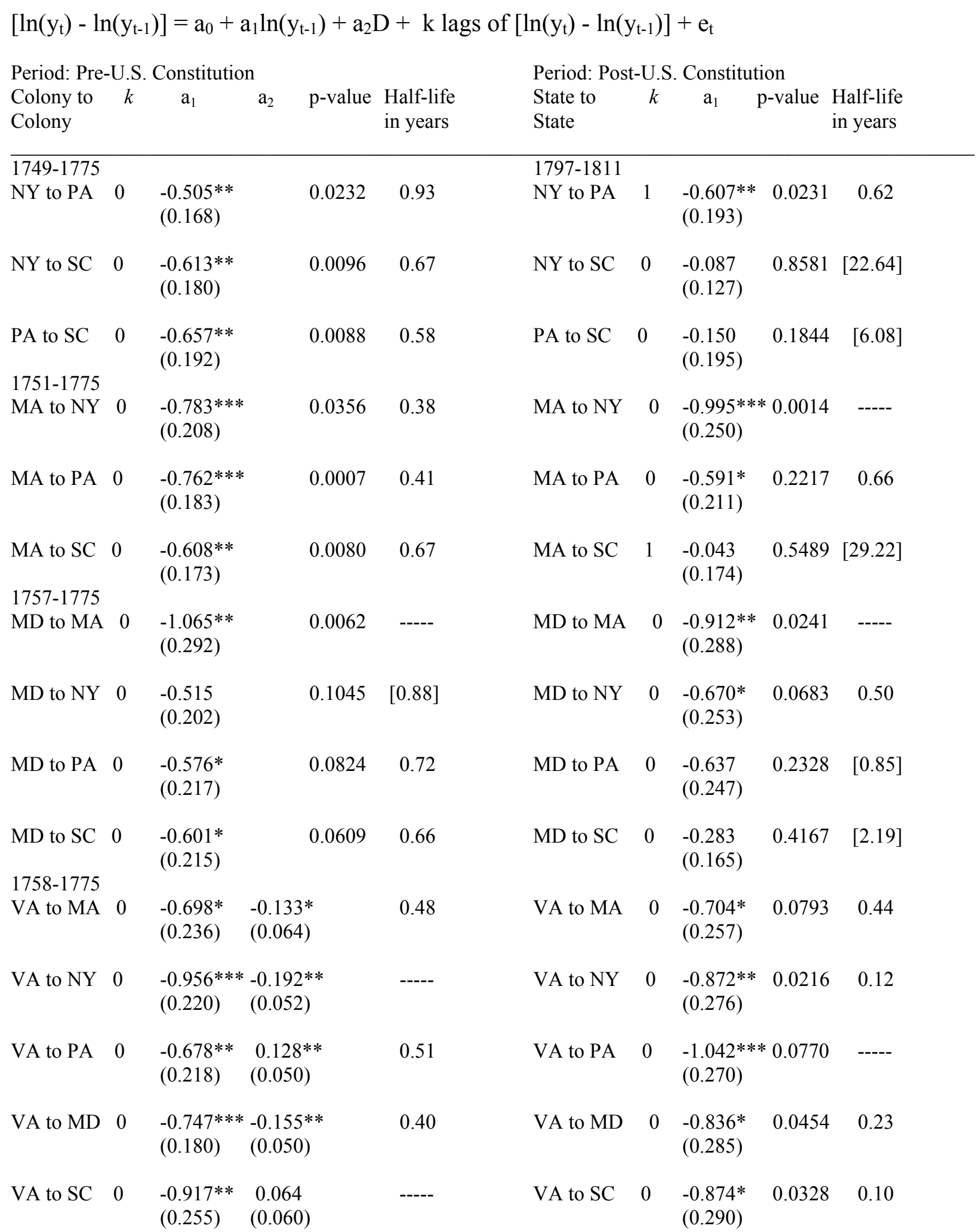




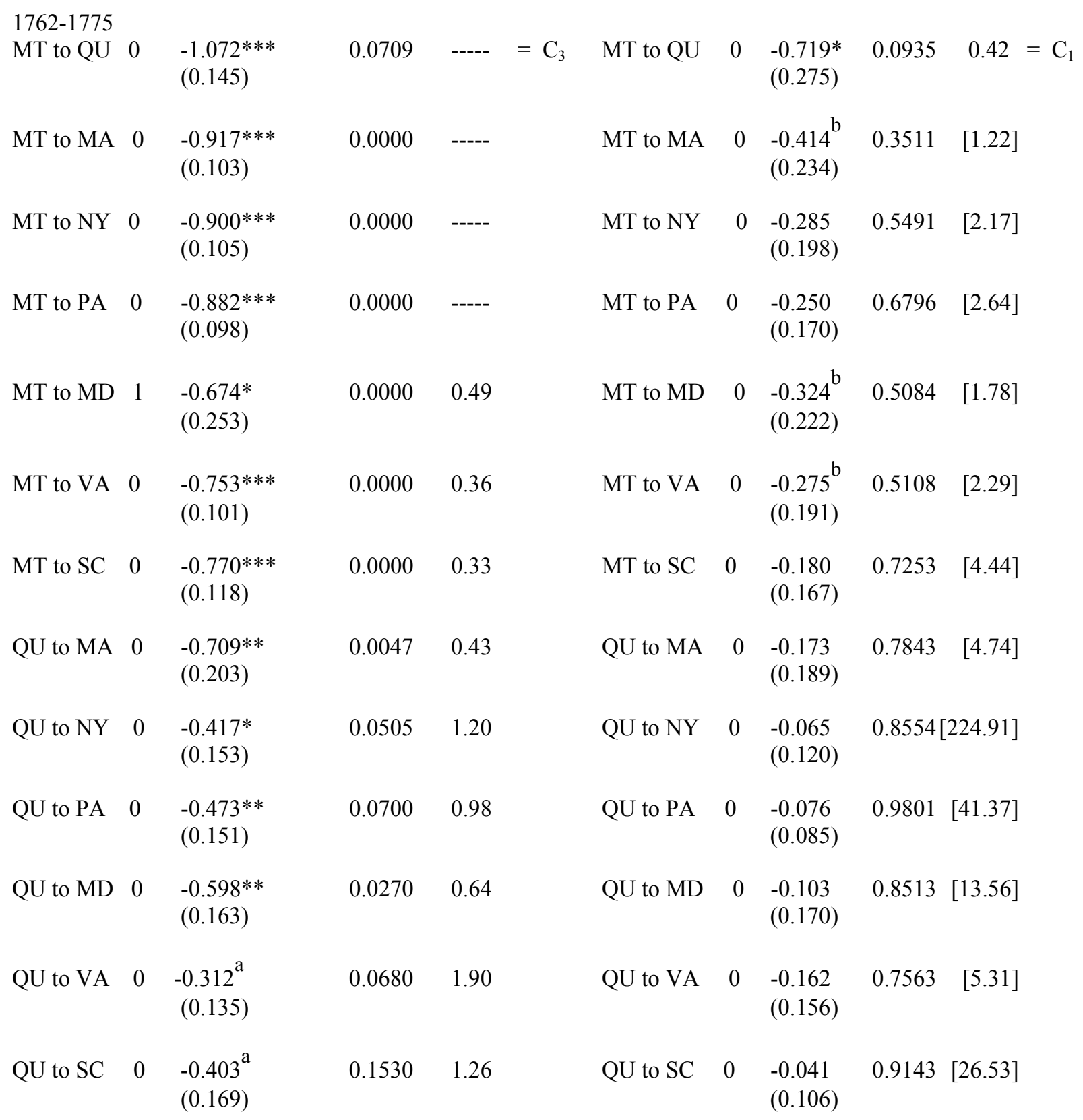

* indicates, ${ }^{* *}$ indicates, and $* * *$ indicates that the coefficient is statistically greater than zero above the 0.1 , the 0.05 , and the 0.01 significance levels, respectively. Dickey-Fuller critical values are used for $\mathrm{a}_{1}$ in the univariate regressions.

${ }^{a}$ If Period is contracted one year to $1763-1775$, then the coefficients on $a_{1}$ become statistically significant above the 0.1 level using Dickey-Fuller critical values. 
${ }^{\mathrm{b}}$ A unit root can be rejected if statistically insignificant lags $(\mathrm{k}=3)$ are added to the specification. In all cases, just the first lag $(\mathrm{k}=1)$ is statistically insignificant at the 0.1 level, and when adding up to three lags $(\mathrm{k}=3)$ the last lag remains statistically insignificant. These specifications also generated coefficients on the $\ln \left(\mathrm{y}_{\mathrm{t}-1}\right) \mathrm{s}$ that are less than -1.0 , suggesting the presence of oscillatory overshooting or excess volatility in the mean reversion process. Notes: $\mathrm{NY}=$ New York, PA = Pennsylvania, $\mathrm{SC}=$ South Carolina, $\mathrm{MA}=$ Massachusetts, $\mathrm{MD}=$ Maryland, VA = Virginia, MT = Montreal (Lower Canada), and QU = Quebec (Lower Canada). The data are yearly. Standard errors are in parentheses. P-values for the univariate regressions are MacKinnon approximate p-values generated by Phillips-Perron univariate tests when structural breaks are not present. Half-life calculations are bias-adjusted following Mark, International Macroeconomics, pp. 32, 44. When this bias-adjusted coefficient is too near to -1 a meaningful half-life different from zero cannot be calculated and is so indicated by a dash. Halflife estimates in brackets represents what the half-life would be if a unit root would have been rejected. Regarding $\mathrm{S}_{1}, \mathrm{~S}_{3}, \mathrm{C}_{1}$, and $\mathrm{C}_{3}$ see note 17 . The panel tests for the pre-U.S. Constitution period do not incorporate the structural break in the Virginia series as was done for the univariate tests. While Period refers to the years spanned by the $\mathrm{y}_{\mathrm{t}}$ values, the existence and use of a $\mathrm{y}_{\mathrm{t}-1}$ value is also implied for the initial year listed. y for the colonial period equals [(Colony A's sterling exchange rate X Colony B's Price Index) / (Colony B's sterling exchange rate X Colony A's Price Index)] for each colony-to-colony pairing, respectively. All cross-colonial exchange rates are derived by combining the respective colony's exchange rates with England, i.e. the number of each colony's pounds per 100 pounds sterling, see Appendix Table A. y for the U.S.dollar national period between U.S. states equals [State A's Price Index / State B's Price Index] for each state-to-state pairing, respectively. All cross-state exchange rates are assumed to be 1 (a 
U.S. dollar is a U.S. dollar). y for the U.S.-dollar national period (1796-1811) for comparison with Canadian locations (MT and QU) equals [Canadian Colony A's Price Index / Canadian Colony B's Price Index] for each Canadian colony-to-Canadian colony comparison (a Halifax pound is a Halifax pound, so exchange rates equal 1), and equals [(Canadian Colony A's Halifax pound to pounds sterling exchange rate times the U. S. State B's Price Index) / (the U.S. dollar to pounds sterling exchange rate times the Canadian Colony A's Price Index)] for each Canadian colony-to-U.S. state pairing, respectively. Lags of the dependent variable were added to the specification until the $\mathrm{k}+1$ lag was statistically insignificant at the 0.1 level. D for Virginia in the univariate regressions is a structural break dummy variable coded as one for the years 1766-75 and zero otherwise (see text for the explanation). For the 1757-75 MD-to-NY univariate regression a unit root can be rejected at the 0.1 level if a $\mathrm{k}=1 \mathrm{lag}$ - which in itself is statistically insignificant—is added to the regression. For the 1797-1811 MD-to-PA univariate regression, a unit root is just barely rejected at the 0.1 level $(\mathrm{t}=2.58)$.

The Massachusetts price index is an annual weighted 15-commodity arithmetic index of rural prices on tradable farm goods with these goods being corn, English hay, meadow hay, potatoes, rye, oats, butter, cheese, milk, fresh beef, salt beef, fresh pork, salt pork, water cider, and clear cider. The Pennsylvania (Philadelphia) price index is a 20-commodity unweighted geometric wholesale price index with the 20 commodities being beef, bread, corn, cotton, flour, gunpowder, indigo, molasses, pitch, pork, rice, rum, salt, staves, sugar, tar, tobacco, turpentine, wheat, and wine. The New York (New York City) price index from 1748 through 1787 is a 15commodity arithmetic wholesale price index and from 1788 through 1811 is a 71-commodity arithmetic wholesale price index. Both use variable group weighting. The 15 commodities are corn, wheat, superfine flour, bread, beef, mess pork, chocolate, coffee, salt, loaf sugar, bohea tea, 
molasses, rum, beeswax, and wood. The 71 commodities include the 15 commodities from 17481787 (sans wood) and oats, rye, tobacco, flaxseed, cotton, butter, cheese, herring, mackerel, common flour, rye flour, saltpeter, cargo pork, pepper, pimento, nutmeg, lump sugar, muscovado sugar, hyson tea, sperm candles, mold candles, dipped candles, whale oil, pig iron, county bar iron, Russian iron, Swedish iron, shot, German steel, nails, nail rods, lead bar, hogshead staves, pipe staves, linseed oil, white lead, white oil lead, glass, tar, pitch, turpentine, brandy, gin, Jamaica spirits, port wine, Madeira wine, castile soap, common soap, pearl ash, pot ash, French indigo, Carolina indigo, beaver, otter, muskrat, marten, and feathers. The South Carolina (Charleston) price index from 1748 through 1775 is a weighted 17-commodity arithmetic wholesale price index with the commodities being rice, indigo, deerskins, pork, corn, pitch, beef, peas, beaver skins, butter, flour, hemp, leather, staves, tallow, tar, and turpentine. From 1780 through 1811 it is a weighted 44-commodity arithmetic wholesale price index which includes the 17 commodities from 1748-1775 (sans beaver skins, hemp, leather, and staves), and short cotton, long cotton, lumber, rosin, tobacco, bacon, beeswax, candles, hams, hay, lard, mackerel, domestic molasses, oats, rope, rum, soap, whiskey, bagging, coffee, brandy, iron bar, foreign molasses, nails, pepper, rum, salt, loaf sugar, muscovado sugar, tea, and Madeira wine. The colonial Maryland price index is an unweighted nine-commodity geometric price index with the nine commodities being corn, wheat, oats, rye, salt, beef, pork, sugar, and rum. The Virginia and post-colonial Maryland price indices are both unweighted three-commodity geometric price indices with the three commodities being corn, wheat, and tobacco. The Montreal and Quebec price indices are both unweighted 10-commodity indices using prices for oats, butter, wood, wheat, beef, flour, hay, eggs, peas, and chickens. 
Sources: Adams, "Prices and Wages," p. 643; Bezanson, et al., Wholesale Prices, pp. 293, 388; Cole, Wholesale Commodity Prices, pp. 11-2, 52, 57-8, 120-2, 135, 154-60; McCullough, Money and Exchange in Canada, pp. 266-8; McCusker, Money and Exchange, pp. 141-2, 164-5, 185-6, 198-9, 211-2, 223-4; Paquet and Wallot, “Some Price Indexes,” pp. 314-5; Rothenberg, “A Price Index,” pp. 975-6, 983-4, 1001; Walsh, "Personal Communication.” The U.S. dollar-to-pound sterling exchange rate is the Baltimore-White banknote adjustment to the true mint parity. See Officer, Between the Dollar-Sterling Gold Points, pp. 51-7, 76, 80-4. Alternative U.S. dollar to pound sterling exchange rates were tried, but none improved the results in terms of PPP holding more strongly over the period used here, see also Grubb, "Creating the U.S. Dollar Currency Union," p. 1795. 
TABLE 2

UNIVARIATE AUGMENTED DICKEY-FULLER TESTS FOR PPP USING ALTERNATIVE SOUTH CAROLINA PRICE INDICES, 1796-1811

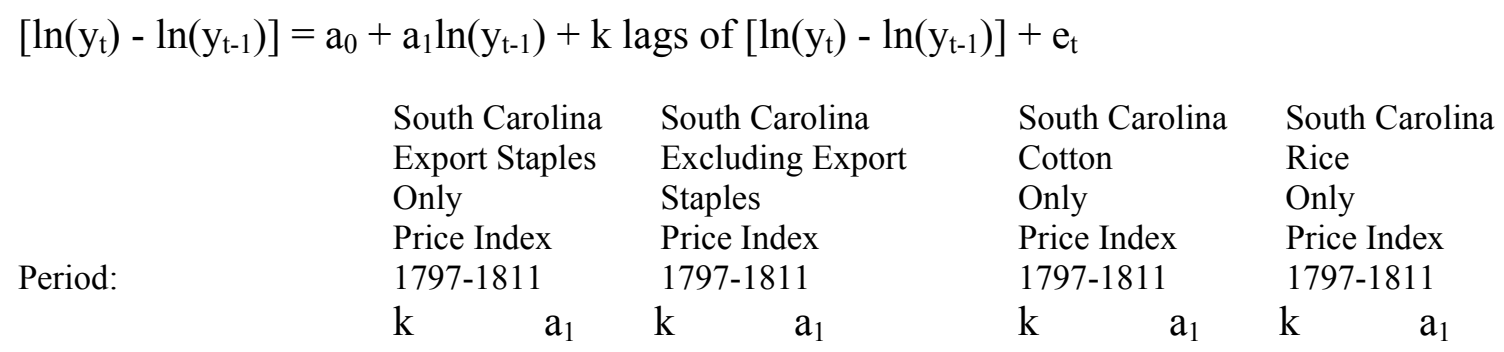

Full Price Index for (unless otherwise indicated):

\begin{tabular}{|c|c|c|c|c|c|c|c|c|}
\hline Montreal & 0 & $\begin{array}{l}-0.137 \\
(0.174)\end{array}$ & 0 & $\begin{array}{l}-0.245 \\
(0.171)\end{array}$ & 0 & $\begin{array}{l}-0.128 \\
(0.159)\end{array}$ & 0 & $\begin{array}{l}-0.346 \\
(0.202)\end{array}$ \\
\hline Quebec & 0 & $\begin{array}{l}-0.013 \\
(0.125)\end{array}$ & 0 & $\begin{array}{l}-0.087 \\
(0.097)\end{array}$ & 0 & $\begin{array}{l}-0.037 \\
(0.120)\end{array}$ & 0 & $\begin{array}{l}-0.311 \\
(0.194)\end{array}$ \\
\hline Massachusetts & 1 & $\begin{array}{c}0.102 \\
(0.160)\end{array}$ & 1 & $\begin{array}{l}-0.294 \\
(0.239)\end{array}$ & 1 & $\begin{array}{l}-0.004 \\
(0.168)\end{array}$ & 2 & $\begin{array}{l}-0.746^{*} \\
(0.263)\end{array}$ \\
\hline New York & 0 & $\begin{array}{l}-0.047 \\
(0.158)\end{array}$ & 0 & $\begin{array}{l}-0.287 \\
(0.189)\end{array}$ & 0 & $\begin{array}{l}-0.052 \\
(0.134)\end{array}$ & 0 & $\begin{array}{l}-0.367^{\mathrm{a}} \\
(0.213)\end{array}$ \\
\hline Pennsylvania & 0 & $\begin{array}{l}-0.082 \\
(0.214)\end{array}$ & 0 & $\begin{array}{l}-0.509 \\
(0.241)\end{array}$ & 0 & $\begin{array}{l}-0.079 \\
(0.172)\end{array}$ & 0 & $\begin{array}{l}-0.355^{\mathrm{a}} \\
(0.211)\end{array}$ \\
\hline $\begin{array}{l}\text { Pennsylvania } \\
\text { Textile Fiber Price } \\
\text { Only Index }\end{array}$ & 0 & $\begin{array}{l}-0.320 \\
(0.193)\end{array}$ & 0 & $\begin{array}{l}-0.695 \\
(0.311)\end{array}$ & 0 & $\begin{array}{l}-0.194 \\
(0.150)\end{array}$ & 0 & $\begin{array}{l}-0.412^{a} \\
(0.224)\end{array}$ \\
\hline $\begin{array}{l}\text { Pennsylvania } \\
\text { Grain Price } \\
\text { Only Index }\end{array}$ & 0 & $\begin{array}{l}-0.124 \\
(0.242)\end{array}$ & 0 & $\begin{array}{l}-0.571 \\
(0.253)\end{array}$ & 0 & $\begin{array}{l}-0.041 \\
(0.176)\end{array}$ & 0 & $\begin{array}{l}-0.335 \\
(0.210)\end{array}$ \\
\hline Maryland & 0 & $\begin{array}{l}-0.155 \\
(0.162)\end{array}$ & 0 & $\begin{array}{l}-0.475 \\
(0.219)\end{array}$ & 0 & $\begin{array}{l}-0.109 \\
(0.131)\end{array}$ & 1 & $\begin{array}{l}-0.572 * \\
(0.216)\end{array}$ \\
\hline Virginia & 1 & $\begin{array}{c}0.051 \\
(0.376)\end{array}$ & 0 & $\begin{array}{l}-1.156^{* *} \\
(0.262)\end{array}$ & 0 & $\begin{array}{l}-0.236 \\
(0.224)\end{array}$ & 0 & $\begin{array}{l}-0.428^{\mathrm{a}} \\
(0.225)\end{array}$ \\
\hline
\end{tabular}

* indicates, and $* *$ indicates, that the coefficient is statistically greater than zero above the 0.1 , and the 0.05 , significance levels, respectively, using Dickey-Fuller critical values. 
${ }^{a}$ If one or two statistically insignificant lags are added to the specification then the coefficients on $\mathrm{a}_{1}$ become statistically significant above the 0.1 using Dickey-Fuller critical values.

Notes: See the notes to Table 1. South Carolina Export Staples Only Price Index included cotton, indigo, rice, tar, tobacco, and turpentine, and received weights of $65,7,15,3,7$, and 3 percent in the index, respectively. South Carolina Excluding Export Staples Price Index included bacon, beeswax, corn, flour, pork, American rum, cognac brandy, foreign molasses, Jamaican rum, Liverpool salt, and muscovado sugar, and receive weights of $6,2,16,15,7,14,3,7,2,10$, and 18 percent in the index, respectively. The Pennsylvania Textile Fiber Price Only Index is an unweighted arithmetic index of cotton, flax, hemp, and wool prices. The Pennsylvania Grain Only Price Index is an unweighted arithmetic index of corn, oats, rice, rye, and wheat prices. Sources: See the source note to Table 1; Bezanson, et al., Wholesale Prices, pp. 13-6, 388, 394-5. 
APPENDIX: TABLE A. Indirect Exchange Rates between American Colonies, 1748-1775

\begin{tabular}{|c|c|c|c|c|c|c|c|c|c|c|c|}
\hline Year & $\begin{array}{c}\mathrm{MA} / \\
\mathrm{NY}\end{array}$ & $\begin{array}{c}\text { MA/ } \\
\text { PA }\end{array}$ & $\begin{array}{c}\text { MA/ } \\
\text { MD }\end{array}$ & $\begin{array}{c}\mathrm{MA} / \\
\mathrm{VA}\end{array}$ & $\begin{array}{c}\mathrm{MA} / \\
\mathrm{SC}\end{array}$ & $\begin{array}{c}\mathrm{NY} / \\
\mathrm{PA}\end{array}$ & $\begin{array}{r}\mathrm{NY} / \\
\mathrm{MD}\end{array}$ & $\begin{array}{c}\mathrm{NY} / \\
\mathrm{VA}\end{array}$ & $\begin{array}{c}\mathrm{NY} / \\
\mathrm{SC}\end{array}$ & $\begin{array}{l}\text { PA/ } \\
\text { MD }\end{array}$ & $\begin{array}{r}\mathrm{PA} / \\
\mathrm{VA}\end{array}$ \\
\hline 1748 & & & & & & 1.0532 & & & 0.2405 & & \\
\hline 1749 & & & & & & 1.0296 & & & 0.2433 & & \\
\hline 1750 & 0.7658 & 0.8050 & & & 0.1956 & 1.0512 & & & 0.2554 & & \\
\hline 1751 & 0.7346 & 0.7849 & & & 0.1905 & 1.0685 & & & 0.2593 & & \\
\hline 1752 & 0.7485 & 0.7892 & & & 0.1881 & 1.0544 & & & 0.2513 & & \\
\hline 1753 & 0.7247 & 0.7762 & & & 0.1857 & 1.0711 & & & 0.2563 & & \\
\hline 1754 & 0.7419 & 0.7920 & & & 0.1905 & 1.0675 & & & 0.2567 & & \\
\hline 1755 & 0.7402 & 0.7899 & & & 0.1905 & 1.0672 & & & 0.2573 & & \\
\hline 1756 & 0.7300 & 0.7726 & 0.8081 & & 0.1869 & 1.0584 & 1.1070 & & 0.2560 & 1.0459 & \\
\hline 1757 & 0.7474 & 0.8029 & 0.8104 & 0.9543 & 0.1904 & 1.0743 & 1.0843 & 1.2769 & 0.2548 & 1.0094 & 1.1887 \\
\hline 1758 & 0.7436 & 0.8072 & 0.8174 & 0.9305 & 0.1833 & 1.0855 & 1.0993 & 1.2515 & 0.2466 & 1.0127 & 1.1528 \\
\hline 1759 & 0.7657 & 0.8399 & 0.8386 & 0.9212 & 0.1842 & 1.0969 & 1.0952 & 1.2030 & 0.2406 & 0.9985 & 1.0968 \\
\hline 1760 & 0.7748 & 0.8167 & 0.8380 & 0.9159 & 0.1851 & 1.0542 & 1.0816 & 1.1822 & 0.2389 & 1.0261 & 1.1215 \\
\hline 1761 & 0.7723 & 0.8112 & 0.8311 & 0.9748 & 0.2001 & 1.0504 & 1.0761 & 1.2623 & 0.2592 & 1.0245 & 1.2017 \\
\hline 1762 & 0.7501 & 0.8075 & 0.8341 & 0.9339 & 0.2033 & 1.0766 & 1.1112 & 1.2451 & 0.2711 & 1.0329 & 1.1566 \\
\hline 1763 & 0.7283 & 0.7861 & 0.8132 & 0.8506 & 0.1898 & 1.0794 & 1.1165 & 1.1679 & 0.2606 & 1.0344 & 1.0821 \\
\hline 1764 & 0.7236 & 0.7738 & 0.8020 & 0.8321 & 0.1863 & 1.0694 & 1.1084 & 1.1501 & 0.2575 & 1.0365 & 1.0755 \\
\hline 1765 & 0.7505 & 0.7860 & 0.8013 & 0.8328 & 0.1883 & 1.0759 & 1.0969 & 1.1399 & 0.2577 & 1.0195 & 1.0595 \\
\hline 1766 & 0.7508 & 0.8163 & 0.8112 & 1.0354 & 0.1882 & 1.0873 & 1.0804 & 1.3791 & 0.2506 & 0.9937 & 1.2684 \\
\hline 1767 & 0.7450 & 0.8031 & 0.8101 & 1.0621 & 0.1905 & 1.0779 & 1.0873 & 1.4255 & 0.2557 & 1.0087 & 1.3225 \\
\hline 1768 & 0.7413 & 0.8002 & 0.8085 & 1.0667 & 0.1905 & 1.0795 & 1.0907 & 1.4391 & 0.2570 & 1.0103 & 1.3331 \\
\hline 1769 & 0.7529 & 0.8242 & 0.8082 & 1.0647 & 0.1833 & 1.0946 & 1.0734 & 1.4140 & 0.2434 & 0.9806 & 1.2918 \\
\hline 1770 & 0.7614 & 0.8206 & 0.8363 & 1.0704 & 0.1762 & 1.0778 & 1.0985 & 1.4059 & 0.2314 & 1.0191 & 1.3044 \\
\hline 1771 & 0.7472 & 0.8047 & 0.8238 & 1.0787 & 0.1750 & 1.0769 & 1.1025 & 1.4436 & 0.2342 & 1.0238 & 1.3405 \\
\hline 1772 & 0.7561 & 0.8145 & 0.8258 & 1.0600 & 0.1929 & 1.0774 & 1.0923 & 1.4020 & 0.2552 & 1.0139 & 1.3013 \\
\hline 1773 & 0.7439 & 0.7950 & 0.8005 & 1.0188 & 0.1816 & 1.0688 & 1.0762 & 1.3696 & 0.2441 & 1.0069 & 1.2815 \\
\hline 1774 & 0.7491 & 0.7984 & 0.8097 & 1.0384 & 0.1933 & 1.0659 & 1.0809 & 1.3862 & 0.2580 & 1.0141 & 1.3005 \\
\hline 1775 & 0.6846 & 0.7290 & 0.7496 & 0.9788 & 0.1548 & 1.0647 & 1.0949 & 1.4296 & 0.2261 & 1.0283 & 1.3427 \\
\hline Year & $\begin{array}{l}\mathrm{PA} / \\
\mathrm{SC}\end{array}$ & $\begin{array}{c}\mathrm{MD} / \\
\mathrm{VA}\end{array}$ & $\begin{array}{l}\mathrm{MD} / \\
\mathrm{SC}\end{array}$ & $\begin{array}{l}\mathrm{VA} / \\
\mathrm{SC}\end{array}$ & $\begin{array}{l}\mathrm{CA} / \\
\mathrm{MA}\end{array}$ & $\begin{array}{l}\mathrm{CA} / \\
\mathrm{NY}\end{array}$ & $\begin{array}{c}\mathrm{CA} / \\
\mathrm{PA}\end{array}$ & $\begin{array}{l}\mathrm{CA} / \\
\mathrm{MD}\end{array}$ & $\begin{array}{c}\mathrm{CA} / \\
\mathrm{VA}\end{array}$ & $\begin{array}{c}\mathrm{CA} / \\
\mathrm{SC}\end{array}$ & \\
\hline
\end{tabular}

$1748 \quad 0.2284$ 


\begin{tabular}{|c|c|c|c|c|c|c|c|c|c|c|}
\hline 1749 & 0.2363 & & & & & & & & & \\
\hline 1750 & 0.2429 & & & & & & & & & \\
\hline 1751 & 0.2427 & & & & & & & & & \\
\hline 1752 & 0.2384 & & & & & & & & & \\
\hline 1753 & 0.2393 & & & & & & & & & \\
\hline 1754 & 0.2405 & & & & & & & & & \\
\hline 1755 & 0.2411 & & & & & & & & & \\
\hline 1756 & 0.2418 & & 0.2312 & & & & & & & \\
\hline 1757 & 0.2372 & 1.1777 & 0.2350 & 0.1995 & & & & & & \\
\hline 1758 & 0.2271 & 1.1384 & 0.2243 & 0.1970 & & & & & & \\
\hline 1759 & 0.2193 & 1.0985 & 0.2196 & 0.1200 & & & & & & \\
\hline 1760 & 0.2266 & 1.0930 & 0.2208 & 0.2020 & & & & & & \\
\hline 1761 & 0.2467 & 1.1730 & 0.2408 & 0.2053 & 0.7994 & 0.6173 & 0.6484 & 0.6643 & 0.7792 & 0.1600 \\
\hline 1762 & 0.2518 & 1.1198 & 0.2438 & 0.2177 & 0.7868 & 0.5902 & 0.6354 & 0.6563 & 0.7348 & 0.1600 \\
\hline 1763 & 0.2414 & 1.0460 & 0.2334 & 0.2231 & 0.8671 & 0.6316 & 0.6817 & 0.7052 & 0.7376 & 0.1646 \\
\hline 1764 & 0.2408 & 1.0376 & 0.2323 & 0.2239 & 0.8370 & 0.6056 & 0.6476 & 0.6713 & 0.6965 & 0.1559 \\
\hline 1765 & 0.2395 & 1.0392 & 0.2349 & 0.2261 & 0.7936 & 0.5797 & 0.6237 & 0.6359 & 0.6608 & 0.1494 \\
\hline 1766 & 0.2305 & 1.2764 & 0.2320 & 0.1817 & 0.7516 & 0.5643 & 0.6136 & 0.6097 & 0.7783 & 0.1414 \\
\hline 1767 & 0.2372 & 1.3111 & 0.2351 & 0.1793 & 0.8385 & 0.6247 & 0.6734 & 0.6792 & 0.8905 & 0.1597 \\
\hline 1768 & 0.2380 & 1.3195 & 0.2356 & 0.1796 & 0.8449 & 0.6263 & 0.6761 & 0.6831 & 0.9013 & 0.1609 \\
\hline 1769 & 0.2224 & 1.3174 & 0.2268 & 0.1722 & 0.8619 & 0.6490 & 0.7104 & 0.6966 & 0.9177 & 0.1580 \\
\hline 1770 & 0.2147 & 1.2799 & 0.2106 & 0.1646 & 0.8531 & 0.6496 & 0.7001 & 0.7135 & 0.9132 & 0.1503 \\
\hline 1771 & 0.2174 & 1.3094 & 0.2124 & 0.1622 & 0.8157 & 0.6095 & 0.6564 & 0.6720 & 0.8799 & 0.1427 \\
\hline 1772 & 0.2369 & 1.2835 & 0.2336 & 0.1820 & 0.8260 & 0.6245 & 0.6728 & 0.6822 & 0.8756 & 0.1594 \\
\hline 1773 & 0.2284 & 1.2727 & 0.2268 & 0.1782 & 0.8264 & 0.6147 & 0.6570 & 0.6615 & 0.8419 & 0.1501 \\
\hline 1774 & 0.2421 & 1.2824 & 0.2387 & 0.1861 & 0.8235 & 0.6169 & 0.6575 & 0.6668 & 0.8551 & 0.1592 \\
\hline 1775 & 0.2124 & 1.3057 & 0.2065 & 0.1582 & 0.9077 & 0.6215 & 0.6617 & 0.6804 & 0.8884 & 0.1405 \\
\hline
\end{tabular}

Notes: CA equals the Canadian locations of Montreal and Quebec where the Halifax pound was used as the unit of account money. Indirect exchange rates between colonies can be constructed as follows: the desired (but unknown) exchange rate [EXab] between Colony A and Colony B equals the number of Colony A pounds needed to buy a given amount of Colony B pounds, namely $E X \mathrm{ab}=(\#$ Colony A pounds / \#Colony B pounds $)$. The known exchange rates 
between pounds sterling and Colony A pounds and between pounds sterling and Colony B pounds equals the number of Colony A pounds and the number of Colony B pounds needed to buy a given amount of pounds sterling, namely EXsa = (\#pounds sterling / \#Colony A pounds) and $E X \mathrm{sb}=(\#$ pounds sterling / \#Colony B pounds $)$, respectively. It follows from simple algebra that the unknown exchange rate between Colony A and Colony $\mathrm{B}$ [EXab] equals the ratio of the two known sterling exchange rates $[E X \mathrm{sb} / E X \mathrm{sa}]$, namely $[E X \mathrm{sb} / E X \mathrm{sa}]=[(\#$ pound sterling / \#Colony B pounds) / (\#pounds sterling / \#Colony A Pounds)] = (\#Colony A pounds / \#Colony B pounds $)=E X \mathrm{ab}$. These indirectly calculated exchange rates between each pair of colonies are what are used in the PPP tests in Tables 1 and 2. In other words, indirect exchange rates between colonies are calculated as [(Exchange rate of Colony A to pounds sterling)/ (Exchange rate of Colony B to pounds sterling)] for each colony-to-colony pairing. Rates are reported only for the years used for the PPP estimates reported in Table 1.

Sources: McCullough, Money and Exchange in Canada, pp. 266-8; McCusker, Money and Exchange, pp. 141-142, 164-165, 185-186, 198-199, 211-212, 223-224. 


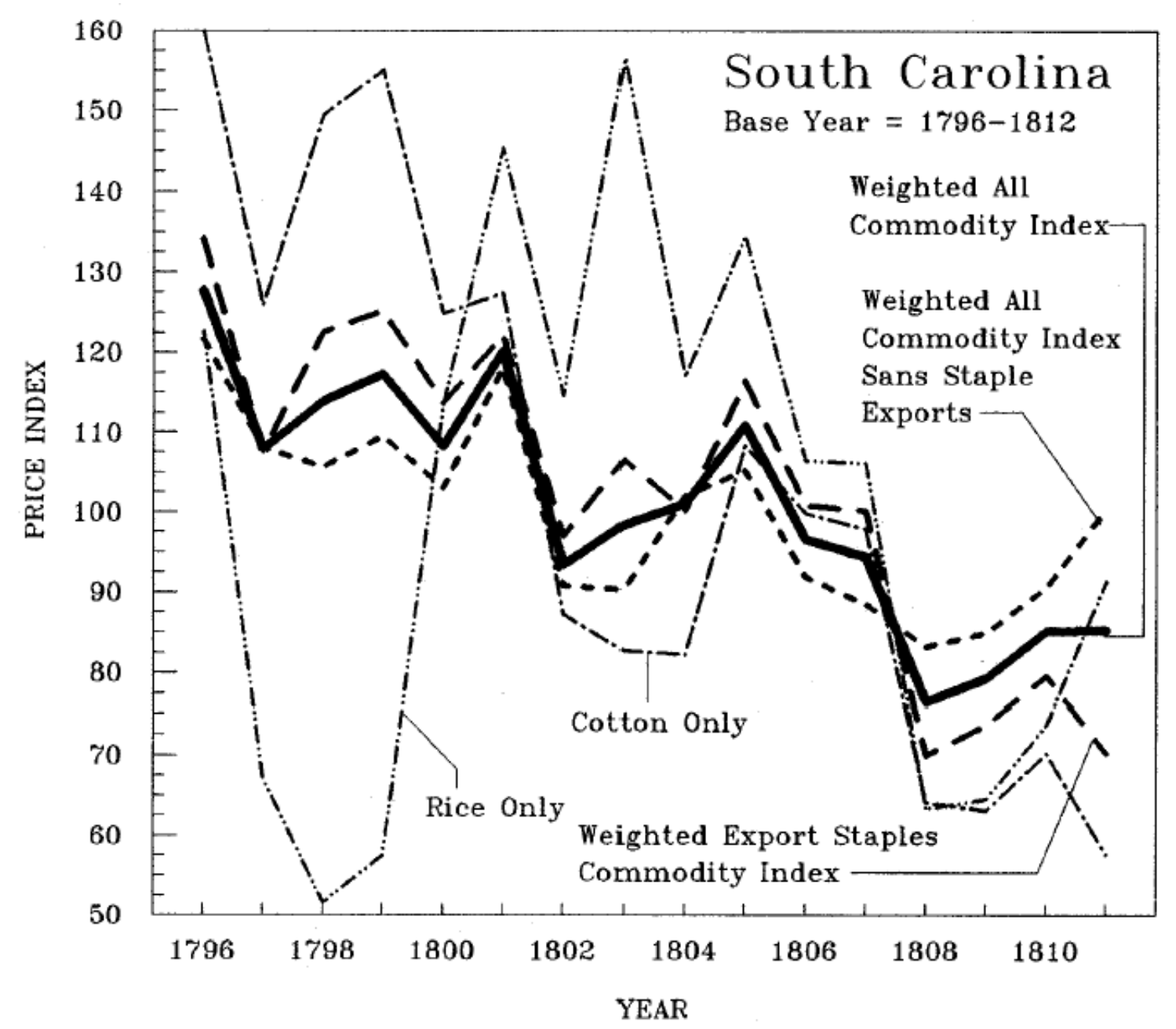

APPENDIX FIGURE A. Component Prices Indices for South Carolina: 1796-1811

Notes: In the "All Commodity Index," the export staple cotton was weighted 32.5 percent and rice 7.5 percent (out of 100 percent). Among the non-export stables in the "All Commodity Index," the seven most heavily weighted goods, out of 100 percent, were sugar ( 9 percent $)$, corn (8 percent), flour (7.5 percent), American Rum (7 percent), Liverpool Salt (5 percent), foreign molasses (3.5 percent), and pork (3.5 percent).

Sources: Derived from Cole, Wholesale Commodity Prices, pp. 57-8, 154, 159-60). 


\section{Footnotes:}

${ }^{1}$ For example, see Bruchey, Roots, pp. 96-7; McCurdy, “American Law”; Walton and Shepherd, Economic Rise, pp. 186-8.

${ }^{2}$ Recently, scholars have examined anew the design and adoption of the U.S. Constitution with an eye on identifying the determinants and motivations of the founding fathers in adopting specific clauses into the Constitution, e.g. see Grubb, "US Constitution and Monetary Powers"; Heckelman and Dougherty, “An Economic Interpretation of the Constitution”; McGuire, To Form a More Perfect Union. This scholarship, including the prior research from which it was derived, has not examined the actual impact on the economy of the specific constitutional clauses so adopted. By contrast, the emphasis here is on measuring economic outcomes rather than inferring motives or identifying behavioral determinants of the founding fathers.

${ }^{3}$ See Bailyn, Debate; Farrand, Records; Dougherty, Collective Action, pp. 72-3, 128-79; Grubb, "US Constitution and Monetary Powers"; Holton, Unruly Americans; Jensen, New Nation, pp. ix, 87, 106, 177, 187-93, 245-7, 337, 347, 399-428; Journals of the Continental Congress, v. 26-34; Tindall, America, pp. 262-93. After the Revolution, the U.S. operated only five full years under the Articles of Confederation, 1784-1788, most of which were severe recessionary years. The quantity and quality of data during these five years are not good enough to support time series analysis. Thus, besides being an inappropriate counterfactual, this period in practice cannot serve in a time-series capacity as a proxy for what market integration would have been under the next best alternative to the Constitution.

${ }^{4}$ Whether the almost-adopted interstate trade rules in the prior drafts of the Constitution at the 1787 Convention can be considered the next best institutional alternative with respect to those rules is hard to say. These alternative rules may not represent the full opportunity cost to the 
Constitution regarding economic integration among the states. Thus, measuring interstate economic integration achieved under the Constitution against that achieved under these alternative rules will likely overstate the net gains in integration attributable to the Constitution.

${ }^{5}$ How congressional consent would work was not discussed at the Constitutional Convention. Most likely Congress could only review and consent to an actual bill passed by a state legislature. As such, Congress would have to actively disallow a particular bill passed by a state legislature to stop its operation. If Congress did not actively disallow the bill but instead remained silent, that would be consent because, in law, silence is consent. This was the same procedure followed by the British Board of Trade regarding colonial legislation. The Board had the right of review and consent which was operationally the right to actively disallow a particular act passed by a colonial legislature or let it stand by inaction and silence on the matter.

${ }^{6}$ Farrand, Records, v. 2, pp. 135-43, 157-8, 181, 187, 441-3.

${ }^{7}$ See Farrand, Records, v. 2, pp. 129-75; Grubb, "US Constitution and Monetary Powers."

${ }^{8}$ Bailyn, Debate, p. 94—Federalist Paper \#44; Farrand, Records, v. 1, pp. 26, 162-73, 288, 327 ; v. 2 , pp. 52 , $75-6,299$; v. 3 , pp. $150,214,607$; v. 4, pp. $44-5$.

${ }^{9}$ Becker, Revolution, pp. 8-112; Hill, "First Stages of the Tariff Policy," pp. 461-90; Hughes, Social Control, pp. 126-43, 159; Owings, His Lordship's Patronage, pp. 59-67; Rabushka, Taxation, pp. 482, 493, 500-1, 508, 510, 517, 525, 588, 606-9, 620, 635-8, 654-5, 669-73, 682-3, 690-4, 703-5, 710, 769-75, 784-6, 793, 804, 838-49, 855-60. Individual states under the Articles of Confederation exercised comparable sovereignty over taxing and regulating the trade that crossed their borders, see Bullock, "Historical Sketch," pp. 285-7; Cooper, Statutes at Large of South Carolina, v. 5; Edling and Kaplanoff, “Alexander Hamilton's Fiscal Reform”; Hill, "First Stages of the Tariff Policy," pp. 490-527, 550, 586-91, 597-603; Jensen, New Nation, pp. 227, 
282-301, 401, 407; Pennsylvania [State of], Statutes at Large of Pennsylvania, v. 11, 12.

${ }^{10}$ Brodhead, History of the State of New York, p. 408; Dickerson, American Colonial

Government, pp. 249-51; Hughes, Social Control, p. 159; Labaree, Royal Government, pp. 218-

68; Rabushka, Taxation, pp. 332-3, 482, 500-1, 510, 517, 606-7, 637, 775. Under British

imperial trade policy and the navigation acts the British North American colonies faced by-andlarge the same uniform application of trade and shipping restrictions within versus without the Empire, see Walton and Shepherd, Economic Rise, pp. 64-95, 182-201.

${ }^{11}$ See Rabushka, Taxation, pp. 482, 510. Jensen, New Nation, pp. 337-42, 423, argues that states under the Articles of Confederation did not construct trade barriers between themselves due to the threat of retaliation and thus "Reciprocity and equal treatment of all United States citizens was the rule in the tonnage and tariff acts of the states [pre-1789], not trade barriers." State tariff laws passed between 1782 and 1789 did in fact explicitly exempt goods that were locally grown or manufactured in other states from paying said duties when transported across state borders, see Cooper, Statutes at Large of South Carolina, v. 5, pp. 8-11; Hill, "First Stages of the Tariff Policy," pp. 598-9, 602; Pennsylvania [State of], Statutes at Large of Pennsylvania, v. 11, pp. 149-50, 329.

${ }^{12}$ Brock, Currency; Ernst, Money and Politics; Grubb, “Creating the U.S. Dollar Currency Union”; Grubb, "Circulating Medium of Exchange”; Grubb, "US Constitution and Monetary Powers"; McCusker, Money and Exchange; Perkins, Economy of Colonial America, pp. 161-95; Perkins, American Public Finance, pp. 29-55; Rabushka, Taxation, pp. 558-863.

${ }^{13}$ This may also be a biased high measure of the impact of the Constitution on increasing market integration among the states in the early national period because unsynchronized real trade shocks between individual colonies and states that might directly disrupt market integrating 
arbitrage would appear to have been greater during the late colonial era (1748-1775) than during the early national era (1796-1811). The disruptions to cross-colony trade caused by the Seven Years' War, and the commercial protests against the Stamp Act, the Townsend Duties, the 1769 importation boycotts, the Boston Massacre, the Tea Act, and the closing of Boston harbor, make the period from 1796 to 1811 look comparatively uneventful in terms of unsynchronized real shocks to cross-state trade. Real trade shocks during the early national period (1796-1811), e.g. trade disruptions due to the Napoleonic Wars, treaty changes, Jefferson's trade embargo, and so forth, were mostly international events that affected all U.S. states more-or-less equally vis-à-vis market integration between the states. Based solely on internal real trade shocks, market integration should have been better in the early national era than in the late colonial era.

${ }^{14}$ Prices are dominated by monetary factors and money is neutral in the long run. Thus, PPP should hold in the long run. See Froot and Rogoff, "Perspectives on PPP," pp. 1650-1.

${ }^{15}$ The half-life to shocks is an issue of the magnitude of the estimated coefficient in the PPP regression ( $\mathrm{a}_{1}$ in the tables below), whereas whether a unit root can be rejected and so PPP holds is an issue of the statistical significance or $p$-value of that coefficient. See Cecchetti, et. al., “Price Index Convergence,” p. 1082; Enders, Applied Econometric Time Series, pp. 234-5; Engel and Rogers, "How Wide is the Border?," pp. 1113-4; Froot and Rogoff, "Perspectives on PPP," pp. 1649-51; Mark, International Macroeconomics, pp. 32-3, 62-5, 170-7; Rogoff, "Purchasing Power Parity Puzzle,” pp. 647-56; Taylor and Taylor, "Purchasing Power Parity Debate."

${ }^{16}$ For example, see North, Economic Growth, pp. 32-5, 57.

${ }^{17}$ The difference-in-difference design can be explained as follows: Let $\mathrm{S}_{1}$ equal the PPP actually measured between U.S. states post-Constitution (as say the half-life to shocks in Table 1 below). Let $\mathrm{S}_{2}$ equal the PPP between U.S. states post-Constitution under the next best 
alternative Constitution with respect to interstate trade rules. The net contribution of the U.S. Constitution to national market integration would then be minus $\left[\mathrm{S}_{1}-\mathrm{S}_{2}\right]$ ("minus" because a smaller half-life implies better market integration). $\mathrm{S}_{2}$, however, is not measureable. Let $\mathrm{S}_{3}$ equal the PPP actually measured among the colonies that would become future U.S. states. As argued above, the institutional structure underlying $S_{2}$ and $S_{3}$ are similar and thus $S_{3}$ can be a proxy for $\mathrm{S}_{2}$. The net contribution of the Constitution to national market integration thus becomes minus $\left[S_{1}-S_{3}\right]$. However, because $S_{1}$ and $S_{3}$ are from different time periods $\left[S_{1}-S_{3}\right]$ does not control for time-varying shocks from outside the system. Thus, a difference-in-difference approach is needed. Let $\mathrm{C}_{1}$ equal the PPP actually measured among Canadian locations post-U.S. Constitution, and $\mathrm{C}_{3}$ equal the PPP actually measured among Canadian locations pre-1776. Minus $\left[\mathrm{C}_{1}-\mathrm{C}_{3}\right]$ can serve as a control for time varying shocks from outside the system. Thus, the net contribution of the U.S. Constitution to U.S. national market integration becomes (minus $\left.\left[\mathrm{S}_{1}-\mathrm{S}_{3}\right]-\left[\mathrm{C}_{1}-\mathrm{C}_{3}\right]\right)$. Such a comparison, however, conflates colonial/state borders and national borders. Thus, an alternative difference-in-difference comparison needs to be examined, namely (minus $\left[\mathrm{S}_{1}-\mathrm{C}_{1}\right]-\left[\mathrm{S}_{3}-\mathrm{C}_{3}\right]$ ), i.e. the difference in the contemporaneous difference in PPP between Canada and the U.S. post-U.S. Constitution (when British Canada and the U.S. are separate nations) versus pre-1776 (when all are part of one British Empire). This is the point of including all four comparisons together in Table 1 below. The last comparison is an alternative way of measuring the same net contribution of the U.S. Constitution to U.S. national market integration. The last two comparisons yield the same outcome, namely minus $\left[\mathrm{S}_{1}-\mathrm{S}_{3}-\mathrm{C}_{1}+\mathrm{C}_{3}\right]$.

${ }^{18}$ See Tables 1 and 2 below for details on indices construction and data sources. While the span of time used is relatively short and so the number of yearly observations small, e.g. only 16 years for the post-Constitution period (1796-1811) and at most 28 years for the colonial era 
(1748-1775), the number of individual observations of prices and exchange rates aggregated to get the yearly data is quite large. For example, for Pennsylvania alone this amounts to approximately 11,088 separate data observations in the 44 years covered (20 commodity prices and one exchange rate observed every month for 44 years). Many of the monthly observations are aggregated up from a number of weekly observations as well. As such, the yearly data points are more precisely estimated than may be supposed at first glance.

${ }^{19}$ See Bordo and Marcotte, "Purchasing Power Parity." The transition from colonies to states was not accompanied by major changes in real productivity shocks - preceding as it were the industrial revolution — or in real information, transportation, and transaction costs, see Shepherd and Walton, Shipping, p. 159. As such, the possibility of non-stationary PPP movements via Balassa-Samuelson productivity shocks affecting the relative tradable to non-tradable components in the price indices are mitigated, see Mark, International Macroeconomics, pp. 168-70. Cecchetti, et al., "Price Index Convergence," pp. 1091-3, and Parsley and Wei, “Convergence," pp. 1219-20, also show that the distinction between tradable and non-tradable goods in PPP tests for $20^{\text {th }}$ century U.S. cities is not strong. In addition, the colonial and early national economies were primarily agriculture. Unexpected non-wartime shocks were more climatological than technological. Harvest short-falls in one location could be easily made up by imports from another location. As long as shipping costs and other standard trade barriers were not too high, PPP should hold relatively easily in such economies compared with modern economies where shocks were relatively more technologically based—given that technological transfer is more complex than the shipping of agricultural goods and given that modern goods are more assembled and processed in a manufactured as opposed to a harvested sense. The yearto-year or seasonal nature of the agricultural cycle may make the use of yearly data for the 
colonial and early national periods more appropriate than the use of yearly data in modern era studies of PPP, see Taylor, "Potential Pitfalls."

${ }^{20}$ See McCullough, Money and Exchange in Canada, pp. 266-8; McCusker, Money and Exchange, pp. 141-2, 164-5, 185-6, 198-9, 211-2, 223-4.

${ }^{21}$ Appendix Table A gives the actual rates generated across the eight locations by year.

${ }^{22}$ See the notes to Table 1 below.

${ }^{23}$ Crossing such regimes could impart heteroscedasticity to the residuals thus violating the assumption of homoscedasticity embedded in most panel estimating algorithms. Restricting the data to homogeneous regimes mitigates this possibility. See Sjölander, "Unreal Exchange Rates."

${ }^{24}$ Bezanson, et al., Wholesale Prices, p. 2; Farrand, Records, v. 2, pp. 583-5, 665-7, v. 3, pp. 349-50; Grubb, “Creating the U.S. Dollar Currency Union,” pp. 1782-3; Grubb, "Constitutional Creation"; Journals of the Continental Congress, v. 33, 34; Kaplan, Bank of the United States, p. 28; North, Economic Growth, pp. 17-8, 46; Perkins, American Public Finance, p. 247; Walradt, "Financial History of Connecticut," p. 19.

${ }^{25}$ See Bezanson, et al., Wholesale Prices, pp. 388-9; North, Economic Growth, pp. 57-8. While Louisiana was not one of the original British colonies that became a U.S. state, it came under American authority after 1802, and price indices for New Orleans exist for 1800-1811 and 18041811 (Cole, Wholesale Commodity Prices, pp. 65-70, 170-1). The 1800-1811 index is based on few commodities and relies more heavily on price evidence derived from "up-stream" sources compared with the 1804-1811 index. PPP between New Orleans and all the other U.S. states, including the subcomponents of the South Carolina price index, as well as for Lower Canada, including the domestic versus foreign subcomponents of the New Orleans price index, were estimated for the two separate periods of 1800-1811 and 1804-1811. Given that the data span is 
very short, not too much should be expected from these estimates. If the results show that PPP could not be rejected for New Orleans in reference to the other U.S. states, this would be strong evidence of market integration within the U.S. under the auspices of the integrating effect of the U.S. Constitution. If the results show that PPP failure cannot be statistically rejected, then it may likely be that the result is just an outcome of too short a data span given the low-powered nature of PPP tests, and so not much can be concluded from this statistical exercise. The results (not reported) show that either PPP failure cannot be statistically rejected in most cases, or in the few cases where PPP failure can be rejected the coefficient magnitudes suggest that the process is highly volatile and unstable. As such, the data span is probably too short to support any conclusion regarding PPP between New Orleans and the other U.S. states in this period.

${ }^{26}$ See McCullough, Money and Exchange in Canada, pp. 67-85; McIvor, Canadian, pp. 11-23.

${ }^{27}$ See Brock, Currency; Ernst, Money and Politics, p. 86; Grubb, "Creating the U.S. Dollar Currency Union"; Grubb, “Circulating Medium of Exchange”; Perkins, Economy of Colonial America, pp. 168-83; Perkins, American Public Finance, pp. 39-55; Rabushka, Taxation.

${ }^{28}$ These properties have been estimated and discussed at length elsewhere, see Grubb, “Creating the U.S. Dollar Currency Union," pp. 1784-6, 1792-5; Grubb, "State 'Currencies',” p. 1346. The point of these prior studies was to look at the properties of the individual price index and exchange rate for each separate location alone in order to infer the likely behavior of each location's individual monetary management behavior-the focus being on the effect that adopting Article 1, Section 10, Paragraph 1 into the U.S. Constitution had on individual monetary behavior per colony/state. This is a different question and use of this data than the question asked here, which addresses whether these locations were well integrated trade-wise and whether that level of integration was affected by institutional change in terms of adopting the 
trade-barrier-removing clauses-Article 1, Section 9, Paragraphs 5 and 6; and Section 10, Paragraphs 2 and 3 - into the U.S. Constitution.

${ }^{29}$ See Enders, Applied Econometric Time Series, pp. 355-405; Mark, International Macroeconomics, p. 49.

${ }^{30} \mathrm{PPP}$ is used here in a two-way comparative approach with each approach having four possible outcomes. The first approach is to compare PPP across British North American colonies with PPP across the same locations after they become U.S. states under the U.S. Constitution. Four outcomes are possible. 1) PPP is not rejected and the half-life to shocks mean-revert faster across the states after the adoption of the U.S. Constitution, but is rejected and/or the half-life to shocks mean-revert slower across these same locations when they were colonies. This outcome can be thought of as the conventional wisdom or what most expect the outcome to be. Such a finding would be a trivial contribution for it only confirms what scholars claim to already know. 2) PPP is rejected across all or most locations in both periods. In this case, given the short spans of data and low-powered tests endemic to PPP econometric procedures, the data simply are not good enough to support any conclusion. 3) PPP is not rejected in either period with the half-life to shocks mean-reverting at similar rates, or 4) PPP is not rejected and the half-life to shocks mean-revert faster across colonial locations, but is rejected and/or the half-life to shocks meanrevert slower across the same locations after the adoption of the U.S. Constitution. The last two possible outcomes would be revolutionary findings — smashing our conventional wisdom and opening the door to substantial revision of how we understand the U.S. Constitution as an institutional change to the national economy. This will be shown to be the case below.

The second approach comes from the fact that not all British North American colonies joined the United States. This allows for an alternative perspective on the economic impact of the 
U.S. Constitution regarding market integration. This perspective compares PPP between the British colonies that became U.S. states with that of nearby British colonies that did not become U.S. states, e.g. Lower Canada (Montreal and Quebec). As measured by PPP, did American independence and the adoption of the U.S. Constitution reduce market integration with other nearby markets that chose to stay within the British Empire? Do we see the rise of two identifiable market zones as measured by PPP — the U.S. states and what remained of the British Empire in America? In other words, as measured by PPP, do changes to international sovereign borders matter to market integration in early America?

As with the first approach above, four outcomes are possible. 1) PPP between Canada and the other colonies and states is rejected in both periods. In this case, given the short spans of data and low-powered tests, the data simply are not good enough to support any conclusion. 2) PPP between Canada and the other colonies and states is not rejected and the half-life to shocks mean-revert at similar rates in both periods. Such a finding would be revolutionary in that it would indicate that the U.S. Constitution had no relative impact on market integration and that international sovereign borders do not matter to PPP here. 3) PPP between Canada and the other colonies is rejected, but between Canada and the U.S. states is not rejected. Such a finding would be revolutionary in that it would indicate that the U.S. Constitution produced nothing unique regarding market integration across the states, even if PPP held better post versus preConstitution across U.S. locations. Such a possible outcome provides a check on the first approach-first outcome listed above (the difference-in-difference approach, see footnote 16). It would indicate that this outcome (first approach-first outcome) is not a sufficient condition by itself to warrant concluding that the U.S. Constitution was the underlying cause for any subsequent increase in market integration within the U.S. Finally, 4) PPP between Canada and 
the other colonies is not rejected, but between Canada and the post-U.S. Constitution states is rejected. Such a finding would indicate that adopting the U.S. Constitution had an international sovereign border effect in a mega-border sense - an inside versus outside the British Empire effect. This last possibility will be shown to be the case below. Since most scholars do not directly address the inside/outside effect on economic integration of adopting the U.S. Constitution, this result is an important new contribution to understanding the economic development of the early Republic.

Combining the results from the two comparative approaches provides rich insight into market integration and institutional change at the constitutional divide. What will be shown is that market integration, as measured by PPP, among the states soon after adopting the U.S. Constitution was not superior to that before 1776. The constitutional clauses eliminating both real and monetary trade barriers between states seem irrelevant, of no import or impact compared with a far looser confederation such as what existed within the British Empire. However, after 1795 a significant gap in market integration, as measured by PPP, does open up between the states as a group (the United States) and the rest of the British Empire in America, a gap that did not exist before 1776. The U.S. Constitution affected market integration at the international level not at the national level. Changing the sovereignty of state borders did not matter (our modern impressions to the contrary), but changing the sovereignty of international borders - the U.S. versus British Canada-did.

${ }^{31}$ See Levin, Lin, and Chu, "Unit Root Tests"; Mark, International Macroeconomics, pp. 3949; and the descriptions of these tests in STATA.

${ }^{32}$ See Mark, International Macroeconomics, p. 48; and Table 1 above. 
${ }^{33}$ The results for the colonial period are consistent with what seems to be the magnitude of inter-colony trade. While data on the volume of inter-colony trade do not exist, the amount of registered ship tonnage entering and clearing colonial regional ports by the ships' origins and destinations between 1768 and 1772 provides a sense of the extent of direct inter-colony trade, see Walton, "New Evidence on Colonial Commerce," p. 366. This measure shows that a substantial amount of ship tonnage went directly between the colonies — often exceeding that going directly to and from Britain and Ireland. Shipping time between colonial ports was under half a year, and ports often published newspapers with local price information which were carried between ports. While the data are not good enough to formally test for it using PPP methodology, the same mechanism (threat of retaliatory action) and so perhaps the same outcome (market integration) may have held for the states under the Articles of Confederation, see Dougherty, Collective Action, p. 73; note 11 above.

${ }^{34}$ It is not clearly rejected only for the Maryland-New York pairing. But if one lag of the dependent variable is added to the specification - which lag in itself is statistically insignificant at the 0.1 level-a unit root can then be rejected.

${ }^{35}$ See Brock, Currency, pp. 465-508; Ernst, Money and Politics, pp. 43-88. Grubb, "Creating the U.S. Dollar Currency Union,” p. 1786, found the same outcome for Virginia's exchange rate and PPP with England.

${ }^{36}$ See note 17.

${ }^{37}$ See also Jensen, New Nation, p. 236; Lakwete, Inventing the Cotton Gin, pp. 47-8, 71.

${ }^{38}$ See note 17.

${ }^{39}$ See Bordo and White, "British and French Finance"; North, Economic Growth, pp.18-23;

Tindall, America, pp. 360-61; Walton and Shepherd, Economic Rise, pp. 64-95, 182-201. 
${ }^{40}$ See Engel and Rogers, "How Wide is the Border?"; Froot and Rogoff, "Perspectives on PPP"; Gopinath, et al., "Estimating the Border Effect"; Mark, International Macroeconomics, pp. 166-74; Rogoff, “Purchasing Power Parity Puzzle.” For dissent, see Gorodnichenko and Tesar, "Border Effect or Country Effect?"

${ }^{41}$ Fear that states, post-Revolution, would enact substantial trade barriers and be embroiled in interstate trade disputes were central concerns at the 1785 Mount Vernon Conference and the 1786 Annapolis Convention, precursors to the 1787 Constitutional Convention. However, prior to 1787 no substantive barriers to interstate commerce had developed. Tariffs enacted by states between 1782 and 1789 explicitly exempted goods that were locally produced in other states. Federalist rhetoric portrayed the eminent collapse of the Confederation as being due, in part, to escalating and unmediated trade disputes amongst the states. This rhetoric may have been used, in part, to win ratification of a new constitution that emasculated state powers. See Dougherty, Collective Action, pp. 73, 140-6; Farrand, Records, v. 3, pp. 544-5, 559; Holton, Unruly Americans; McCurdy, “American Law,” pp. 633-4; Rutland, Papers of George Mason, v. 2, pp. 814-22; Walton and Shepherd, Economic Rise, p. 188; note 11 above. Using non-quantitative analysis, Jensen, New Nation, pp. 339-40, 422, reached a similar conclusion and warned that Federalist "partisan propaganda is not history but is only historical evidence."

${ }^{42}$ See Rabushka, Taxation. For example, today Delaware has a sales tax on wine. Because no wine is produced in Delaware, this tax is equivalent to Delaware placing a tariff on wine entering the state from other U.S. states and foreign nations.

${ }^{43}$ See Adams, "Taxation,” pp. 313-5; Brooks, Financial History of Georgia, pp. 15-7; Bullock, “Historical Sketch,” pp. 275-301, 401; Cooper, Statutes at Large of South Carolina, v. 5; Dickinson, Digest of the Common Law; Edling and Kaplanoff, “Alexander Hamilton's Fiscal 
Reform"; Elmer, Digest of the Laws of New Jersey; Hanna, "Financial History of Maryland," pp. 373-86; Hening, Statutes at Large, v. 13, pp. 111-3, 336-7; Herty, Digest of the Laws of Maryland; Maryland [State of], Digest of the Laws of Maryland; Pennsylvania [State of], Statutes at Large of Pennsylvania; Purdon, Digest of the Laws of Pennsylvania; Shepherd, Statutes at Large of Virginia; Sowers, Financial History of New York State, pp. 114-5, 133-41, 324-5, 332-3; Walradt, "Financial History of Connecticut," pp. 9-58; Wolcott, "Direct Taxes". ${ }^{44}$ Between 1782 and 1811 many states had taxes on luxury imported items, such as billiard tables and fancy carriages for human travel, see note 43 . These taxes, however, were property taxes. They taxed ownership not sale. As such, they only reduced local demand without creating any further differential between in-state and out-of-state prices of these goods. Only if such goods, being consumer durables, are measured in terms of implicit rental rates would these property taxes create a further differential between in-state and out-of-state rental rates and so show up as inhibiting interstate market integration. Because the price indices used here do not include such goods and because they are not measured in terms of rental rates, such property taxes do affect the PPP measures used here. For an example of the return of state excise taxes later in the $19^{\text {th }}$ century, see Hood, State Laws of New Jersey, p. 437.

${ }^{45}$ See Sowers, Financial History of New York State, pp. 133, 324-5. From 1804 through at least 1807 Virginia had a merchant's tax that required a license "to sell merchandize of foreign growth or manufacture, by wholesale or retail." This may have had a similar effect as New York's auction duties on inhibiting better interstate market integration. See Shepherd, Statutes at Large of Virginia, v. 3, pp. 23, 114, 205, 354.

${ }^{46}$ At the 1787 Constitutional Convention, George Mason near the end of the Convention on September $12^{\text {th }}$ and $13^{\text {th }}$ moved to add the final piece to the restrictive clause on state trade 
powers, namely that no state shall be restrained from imposing duties for the sole purpose of executing its inspection laws and defraying the costs thereof. Madison saw this change as harmless in that it would restrict states only to bona fide duties in his view. The motion was accepted by an explicit vote of 7 states to 3 states. See Farrand, Records, v. 2, pp. 588-9, 605-7.

${ }^{47}$ See Cooper, Statutes at Large of South Carolina, v. 5, pp. 113-21, 145, 196-7, 215, 260-1, 267, 290-6, 311-2, 384-5, 401-2, 433-4, 603-4, 617-8, 623; Hening, Statutes at Large, v. 13, pp. 41-3, 155-6; Herty, Digest of the Laws of Maryland, pp. 53-62, 294-55, 294-304, 431-3, 501-5; Maryland [State of], Digest of the Laws of Maryland, pp. 126-39; Pennsylvania [State of], Statutes at Large of Pennsylvania, v. 13, pp. 215-9; v. 15, pp. 346-52; v. 16, pp. 46-7, 51-2, 220, 366-68, 482-5, 505-6; v. 17, pp. 434, 508-10, 864-6; v. 18, pp. 519, 888; Purdon, Digest of the Laws of Pennsylvania, pp. 74-84; Shepherd, Statutes at Large of Virginia, v. 1, pp. 145-7, 173-5, 228-9, 258-65, 297, 335, 371-3; v. 2, pp. 18, 20-1, 32-3, 43, 114-8, 127-8, 148-9, 156, 161-8, $180,204-5,207-8,257-8,263-4,266-8,274-5,287-9,318,323-4,335,339-42,350,355,442$, $462-3$; v. 3, pp. $25,44,48,60-1,70-1,178,182,210,216,220-1,225,228,232-3,259-60,309$, $314-5,325,339,417,420-1$.

${ }^{48}$ See McCurdy, "American Law."

49 Taylor, “A Century of Purchasing Power Parity,” p. 149.

${ }^{50}$ See Grubb, "US Constitution and Monetary Powers"; North, Economic Growth, p. 46. In the modern era, PPP is more often rejected during periods of floating exchange rates and when sovereign borders intrude. See Engel and Rogers, "How Wide is the Border?"; Froot and Rogoff, "Perspectives on PPP"; Gopinath, et al., "Estimating the Border Effect"; Mark, International Macroeconomics, pp. 166-74; Rogoff, “Purchasing Power Parity Puzzle.” 
${ }^{51}$ Grubb, "Creating the U.S. Dollar Currency Union"; Landon-Lane and Rockoff, "From Monetary Union to Financial Union"; Perkins, American Public Finance, pp. 235-81; Selgin, "The Suppression of State Banknotes"; Shambaugh, "Experiment with Multiple Currencies." ${ }^{52}$ South Carolina's inspection laws were more extensive than in other states. South Carolina also sought to levy tonnage duties, with congressional consent, at the port of Charleston. See Cooper, Statutes at Large of South Carolina, v. 5, p. 480; note 47.

${ }^{53}$ See Cooper, Statutes at Large of South Carolina, v. 5, pp. 166-7, 188-93, 205-6, 208-10, 225-30, 250-4, 268-9, 273-7, 296-302, 324-9, 340-7, 369-77, 386-97, 417-30, 441-52, 470-77, 483-92, 510-20, 529-39, 549-64, 581-94, 605-17, 625-38, 652-64; Newman, Early Paper, p. 424.

${ }^{54}$ See Cecchetti, et. al. "Price Index Convergence"; Kausik Chaudhuri and Jeffrey Sheen, 2004; Enders, Applied Econometric Time Series, pp. 234-250; Engel and Rogers, "How Wide is the Border?"; Froot and Rogoff, "Perspectives on PPP”; Mark, International Macroeconomics, pp. 62-67, 170-178; Rogoff, "Purchasing Power Parity Puzzle"; Taylor, "Potential Pitfalls"; Taylor, “A Century of Purchasing Power Parity"; Taylor and Taylor, "Purchasing Power Parity Debate." An exception is Parsley and Wei, “Convergence," pp. 1232-3, who estimated half-lives of 1.0 to 1.24 years between major U.S. cities from 1975 to 1992.

${ }^{55}$ See Taylor, "A Century of Purchasing Power Parity"; Taylor and Taylor, "Purchasing Power Parity Debate"; and footnote 19.

${ }^{56}$ See Engel and Rogers, "How Wide is the Border?"; Froot and Rogoff, "Perspectives on PPP”; Mark, International Macroeconomics, pp. 166-174; Rogoff, "Purchasing Power Parity Puzzle"; Taylor, "A Century of Purchasing Power Parity."

${ }^{57}$ Froot and Rogoff, "Perspectives on PPP,” p. 1672. 